\title{
Systematic Review on Infusion Reactions to and Infusion Rate of Monoclonal Antibodies Used in Cancer Treatment
}

\author{
MAURIEN D. ROMBOUTS ${ }^{1}$, ELEONORA L. SWART ${ }^{1}$, \\ ALFONS J.M. VAN DEN EERTWEGH ${ }^{2}$ and MIRJAM CRUL ${ }^{1}$ \\ ${ }^{1}$ Department of Clinical Pharmacy and Pharmacology, \\ Amsterdam UMC, VU Medical Center, Amsterdam, the Netherlands; \\ ${ }^{2}$ Department of Medical Oncology, Amsterdam UMC, \\ VU Medical Center Amsterdam, Cancer Center Amsterdam, Amsterdam, the Netherlands
}

\begin{abstract}
Background: Patients with cancer who are treated with monoclonal antibodies are at risk for developing infusion reactions. However, for some monoclonal antibodies, the incidence of infusion reactions is low or can be lowered by the use of adequate premedication schedules. It is often feasible to increase the infusion rate/lower the post-administration observation time. This review gives an overview of infusion reactions and the possibility of accelerating infusion rates. Materials and Methods: Data on infusion reactions and infusion rates for all monoclonal antibodies that are licensed in the European Union for treatment of solid tumors or hematological malignancies, found by a literature search, were included in this review. Results: For 11 out of the 21 monoclonal antibodies data exceeding the registration text were found and described. Faster infusion schedules are possible for bevacizumab, ipilimumab, nivolumab, panitimumab, and rituximab. Conclusion: We propose optimal infusion schedules for each drug.
\end{abstract}

Monoclonal antibodies have gained an important place in systemic anticancer therapy over the past decade. Moreover, combinations of monoclonal antibodies have now reached first-line treatment options for some tumor types. One of the complications of therapy with monoclonal antibodies is the occurrence of infusion-related reactions. Mild to moderate

This article is freely accessible online.

Correspondence to: M.D. Rombouts, Amsterdam UMC, VU Medical Center (Pharmacy), De Boelelaan 1117, 1081 HV Amsterdam, the Netherlands. E-mail: m.rombouts1@amsterdamumc.nl

Key Words: Monoclonal antibody, infusion reaction, infusion time, infusion rate systematic review, review. infusion reactions are associated with chills, fever, mild hypotension, dyspnea and rash. Severe reactions are less common and are, amongst other symptoms, associated with severe hypotension, anaphylaxis and cardiac dysfunction (1). An infusion reaction usually starts within 30 to $120 \mathrm{~min}$ after the start of administration of the monoclonal antibody, but delayed infusion reactions at up to 24 hours (and even a week for trastuzumab) after infusion have been observed $(2,3)$.

Both conventional cytotoxic drugs and monoclonal antibodies are known to induce infusion reactions. Although the appearance of the infusion reactions to both types of drugs is very similar, the pathophysiology is not. Infusion reactions to monoclonal antibodies are mostly so-called cytokine-release reactions. By binding of the monoclonal antibody to the target cell, cytokines are released into the circulation and cause symptoms (4). Conventional cytotoxic drugs can induce immunoglobulin E ( $\mathrm{IgE}$ )-mediated allergic reactions, inducing the release of vasoactive mediators from mast cells and basophil cells. In this respect, rituximab, trastuzumab and cetuximab are exceptions since they are able to induce both types of infusion reactions. In order to clarify the difference between both types of reactions, the National Cancer Institute Common Toxicity Criteria (NCICTC) uses separate criteria and grades of severity as is shown in Table I (5). Most articles use the NCI-CTC criteria but different definitions of infusion reactions are used in literature, which sometimes makes it difficult to compare information.

The likelihood of a patient having an infusion reaction is not known prior to treatment. It differs per person, disease and type of monoclonal antibody used (3). Avelumab, rituximab and daratumumab have a high rate of infusion reactions. More than half of the patients develop some type of reaction. Trastuzumab and cetuximab are also known for a relatively high rate of infusion reactions [ $40 \%$ and up to 
Table I. Common Terminology Criteria for Adverse Events (CTCAE) for infusion-related and allergic reactions (5).

\begin{tabular}{|c|c|c|c|c|c|}
\hline CTCAE Term & Grade 1 & Grade 2 & Grade 3 & Grade 4 & Grade 5 \\
\hline $\begin{array}{l}\text { Infusion-related } \\
\text { reaction* }\end{array}$ & $\begin{array}{l}\text { Mild transient reaction; } \\
\text { infusion interruption } \\
\text { not indicated; } \\
\text { intervention } \\
\text { not indicated }\end{array}$ & $\begin{array}{l}\text { Therapy or infusion } \\
\text { interruption indicated but } \\
\text { responds promptly to } \\
\text { symptomatic treatment } \\
\text { (e.g. antihistamines, } \\
\text { NSAIDS, narcotics, i.v. fluids); } \\
\text { prophylactic medications } \\
\text { indicated } \leq 24 \mathrm{~h}\end{array}$ & $\begin{array}{l}\text { Prolonged (e.g. not rapidly } \\
\text { responsive to symptomatic } \\
\text { medication and/or } \\
\text { brief interruption of } \\
\text { infusion); recurrence of } \\
\text { symptoms following } \\
\text { initial improvement; } \\
\text { hospitalization indicated } \\
\text { for clinical sequelae }\end{array}$ & $\begin{array}{c}\text { Life threatening } \\
\text { consequences; } \\
\text { urgent intervention } \\
\text { indicated }\end{array}$ & Death \\
\hline $\begin{array}{l}\text { Allergic } \\
\text { reaction** }\end{array}$ & $\begin{array}{l}\text { Systemic intervention } \\
\text { not indicated }\end{array}$ & $\begin{array}{l}\text { Oral intervention } \\
\text { indicated }\end{array}$ & $\begin{array}{l}\text { Bronchospasm; } \\
\text { hospitalization indicated } \\
\text { for clinical sequelae; } \\
\text { i.v. intervention indicated }\end{array}$ & $\begin{array}{l}\text { Life-threatening } \\
\text { consequences; } \\
\text { urgent intervention } \\
\text { indicated }\end{array}$ & Death \\
\hline
\end{tabular}

NSAIDS: Non-steroidal anti-inflammatory drugs. *A disorder characterized by adverse reaction to the infusion of pharmacological or biological substances; **A disorder characterized by an adverse local or general response from exposure to an allergen.

$22 \%$ depending on the investigational area, respectively (6)]. No relationship has been found between the origin of the monoclonal antibody (human, chimeric or mouse) and the incidence of infusion reactions $(1,3)$. The number of administrations and combination therapy with another drug influences the probability of a reaction (3). Most infusion reactions occur during the first or second infusion. However, $10-30 \%$ of infusion reactions happen during subsequent administrations (1). Finally, a higher rate of infusion is associated with a higher likelihood of a reaction (3).

Several options for reducing the risk of infusion-related reactions are available. Firstly, for most monoclonal antibodies, pretreatment with antihistamines, acetaminophen and corticosteroids is mandatory. Secondly, using an incremental escalation of the infusion rate in the first and sometimes second cycle of treatment can prevent infusion reactions. Thirdly, for some monoclonal antibodies, a reduced dose approach in the first cycle is included in the recommended treatment protocols.

Depending on the severity, there are different ways to manage infusion reactions to monoclonal antibodies. Mild to moderate infusion reactions (grade 1 or 2) can be managed by slowing down the infusion rate or by interrupting the infusion until the symptoms disappear, usually this happens within half an hour (6). Afterwards, the infusion can be restarted with half of the infusion rate (4). When the reaction is severe (grade 3 or 4 ), the infusion should be stopped and adequate medical treatment is needed (6). Restarting administration of the monoclonal antibody after a severe reaction is not recommended in most cases (1). However, successful desensitization schemes have been published as case reports or case series for rituximab, trastuzumab, bevacizumab and cetuximab (7).
All monoclonal antibodies have restrictions on their rate of infusion, mostly determined during registration trials. However, it is known that in some cases, faster infusion is safely possible. This review gives an overview of infusion reactions to monoclonal antibodies used for cancer therapy and the relationship between the rate of infusion and occurrence of these reactions. Knowledge about the maximum tolerated infusion rate and the different ways of reducing infusion reactions while finding the perfect infusion rate will help to make administration of monoclonal antibodies more patient-friendly. Faster infusion of monoclonal antibodies when possible will mean less time in the hospital for the patient and also reduce hospital costs at the same time.

\section{Materials and Methods}

All monoclonal antibodies that were licensed in Europe for one or more indications in the field of oncology (including solid tumors as well as hematological malignancies) until January $1^{\text {st }}$ 2019 were included in the review. Monoclonal antibody-drug conjugates such as brentuximab-vedotin and trastuzumabemtansin were excluded, since in these cases possible infusion or allergic reactions might originate from either the monoclonal antibody or the cytotoxic part of the drug, and it is impossible to make a distinction between the two.

For each monoclonal antibody, the summary of product characteristics (SmPC) was screened for data on infusion reactions, infusion rate, observation time and supportive measures for reducing the risk of an infusion reaction. When the SmPC had limited data, the phase III trials were also included and screened in the analysis. Furthermore, a literature search using PubMed was performed for each monoclonal antibody including the key words "infusion reaction", "infusion rate" and "infusion time". Articles that were written in English were included in the analysis. 


\section{Results}

Twenty-one monoclonal antibodies were identified and included in this review. For 10 of these, no additional information on infusion reactions or infusion rates other than those described by the manufacturer has been published. For the other 11, data exceeding the SmPC were found, either as part of post -marketing surveillance studies, or as independent trials investigating accelerated infusion rates. All of the data are summarized in Table II. The monoclonal antibodies for which post-registration information on infusion reactions was found are outlined in alphabetical order below.

Avelumab. The infusion time for avelumab, a fully human IgG1 monoclonal antibody, is 1 hour, unless a grade 1 or 2 infusion reaction occurs (after a grade 3 or 4 reaction, the infusion is stopped). After a grade 1 infusion reaction, the infusion rate should be reduced to $50 \%$. After a grade 2 reaction, the infusion should be temporarily stopped until the severity of the reaction is grade 0 or 1 , whereupon the infusion rate should also be resumed at $50 \%$. According to the SmPC, premedication with an antihistaminic and acetaminophen is recommended at least during the first four infusions of avelumab. According to the SmPC, $98.6 \%$ of patients have an infusion reaction during one of the first four infusions; $2.7 \%$ of these reactions were classified as grade $\geq 3$. After the first four infusions, $1.4 \%$ of patients have an infusion reaction, all classified as grade 1 or $2(8)$. In the phase III study of Barlesi et al., a much lower rate of infusion reaction of $27 \%$ was noted, and it was shown that $99 \%$ of those happened during the first three infusions (9). The SmPC mentions the fact that infusion reactions can occur during but also after cessation of the infusion. However, it is not stated how long a patient should be observed after treatment.

Bevacizumab. By binding to vascular endothelial growth factor, bevacizumab inhibits vascularization of the tumor. It is registered for multiple kinds of cancer, always in combination with other anticancer agents. According to the registration documentation, the first infusion should, independently of the dose, be given intravenously in $90 \mathrm{~min}$. When tolerated, the next infusion can be given in $60 \mathrm{~min}$ and all following cycles in $30 \mathrm{~min}$. No systemic premedication is advised. The SmPC classifies the frequency of infusion reactions as 'often' (up to 5\%) (10). Reidy et al. compared the 90-, 60- and 30-min protocols with an infusion duration of bevacizumab of 30 and $10 \mathrm{~min}$. Retrospectively, more than 8,494 doses of $5 \mathrm{mg} / \mathrm{kg}$ bevacizumab were analyzed, given to 765 patients. No infusion reactions occurred in the group that was treated according to the registration protocol (90-, 60- and 30-min infusions; 202 patients), nor in the group that was treated with a standard infusion time of 30 min. In the group of 370 patients that received bevacizumab with the infusion rate of $0.5 \mathrm{mg} / \mathrm{kg} / \mathrm{min}$, six patients had some symptoms associated with infusion reactions but all were graded as not clinically relevant. They concluded that an infusion rate of $0.5 \mathrm{mg} / \mathrm{kg} / \mathrm{min}$ is safe (11).

After Reidy et al., Mir et al. investigated a faster infusion rate of bevacizumab $(7.5 \mathrm{mg} / \mathrm{kg})$ in $10 \mathrm{~min}$ compared to $90-60$ $30 \mathrm{~min}$ in 91 patients with non-small cell lung cancer. They stated that $7.5 \mathrm{mg} / \mathrm{kg}$ bevacizumab can be safely given in 10 min (12). Gil et al. investigated an infusion rate of 0.5 $\mathrm{mg} / \mathrm{kg} / \mathrm{min}$ in 73 patients and saw only one mild infusionrelated hypersensitive reaction which did not require any treatment with medication (13). Mahfoud et al. compared 5 and $7.5 \mathrm{mg} / \mathrm{kg}$ bevacizumab infusions in $10 \mathrm{~min}$ versus the SmPCstated regimen in patients with metastatic colorectal cancer. They saw only two grade 2 infusion reactions in the 10 -min group (a total of 527 doses given). Since these symptoms were easily treated and comparable to numbers they found in literature, the authors concluded that bevacizumab could be safely infused in $10 \mathrm{~min}$ in this group of patients (14). Shah et al. stated that besides no hypersensitive reactions, there was also no increase in proteinuria and hypertension seen when a 0.5 $\mathrm{mg} / \mathrm{kg} / \mathrm{min}$ bevacizumab infusion was given (15). Yanmaz et al. (16) also showed that infusion in $30 \mathrm{~min}$ was safe. They also did not see any infusion reactions in patients treated with 10 $\mathrm{mg} / \mathrm{kg}$ (four patients) and $15 \mathrm{mg} / \mathrm{kg}$ (one patient).

Altogether, there is enough clinical experience with safe administration of bevacizumab in 30 or even $10 \mathrm{~min}$, in contrast to the registration leaflet which indicates 90-, 60and 30-min infusions.

Cetuximab. Cetuximab is registered for colorectal carcinoma in patients with overexpression of epidermal growth factor receptor (EGFR) and 'wild type' $R A S$ gene, as well as in squamous cell carcinoma in the head and neck. Cetuximab binds to EGFR and inhibits the signal transduction of this pathway. The SmPC recommends the first dose be infused at $400 \mathrm{mg} / \mathrm{m}^{2}$ in $120 \mathrm{~min}$, with a maximum infusion rate of 5 $\mathrm{mg} / \mathrm{min}$. All subsequent infusions of $250 \mathrm{mg} / \mathrm{m}^{2}$ can be infused in $60 \mathrm{~min}$ (maximum of $10 \mathrm{mg} / \mathrm{min}$ ) (17). Infusionrelated reactions of grade 1 or 2 happen 'very often' $(\geq 1 / 10$; $15-21 \%)$. Slowing down the infusion rate is then advised. Infusion-related reactions with grade 3 or 4 happen 'often' $(\geq 1 / 100,<1 / 10 ; 2-5 \%)$ during or after the infusion of cetuximab, despite the use of premedication with a corticosteroid and an antihistaminic. The vast majority of reactions ( $>90 \%$ ) occur during the first cycle, but since later reactions have been observed, an observation period of $1 \mathrm{~h}$ after infusion is recommended (18). In the SmPC, no distinction is made between infusion-related reactions due to allergic, anaphylactic mechanisms and infusion reaction resulting from cytokine release syndrome (CRS). The time 
Table II. Overview of all data and suggested infusion rates for monoclonal antibodies in clinical use.

\begin{tabular}{|c|c|c|c|c|c|}
\hline Drug & Infusion rate & $\begin{array}{l}\text { Incidence of infusion } \\
\text { reactions }\end{array}$ & Premedication & $\begin{array}{l}\text { Observation time } \\
\text { after infusion }\end{array}$ & Ref \\
\hline Atezolizumab & $\begin{array}{l}\text { First dose }(1,200 \mathrm{mg}) \text { in } 60 \mathrm{~min} \text {, } \\
\text { subsequent doses in } 30 \mathrm{~min} .\end{array}$ & Seen 'often' $(\geq 1 / 100,<1 / 10)$ & Can be considered & Not mentioned & 67 \\
\hline \multirow[t]{2}{*}{ Avelumab } & All dose $(10 \mathrm{mg} / \mathrm{kg})$ in $60 \mathrm{~min}$ & $\begin{array}{c}98.6 \% \text { During the first four } \\
\text { infusions (very often } \geq 1 / 10 \text { ) } ; 2.7 \% \\
\text { of these were classified as grade } \geq 3 \text {. } \\
1.4 \% \text { After the first four } \\
\text { infusions, all were classified } \\
\text { as grade } 1 \text { or } 2 .\end{array}$ & $\begin{array}{l}\text { Antihistamine and } \\
\text { acetaminophen at } \\
\text { least during the } \\
\text { first four infusions. }\end{array}$ & $\begin{array}{c}\text { Not specified } \\
\text { but recommended }\end{array}$ & 8 \\
\hline & $10 \mathrm{mg} / \mathrm{kg}$ in $60 \mathrm{~min}$ & $\begin{array}{l}15 \% \text { Grade } 1-2,1 \% \text { grade } 3, \\
<1 \% \text { grade } 4,99 \% \text { during the } \\
\text { first three infusions }\end{array}$ & $\begin{array}{c}25-50 \mathrm{mg} \\
\text { Diphenhydramine } \\
\text { p.o. and } 500-600 \mathrm{mg} \\
\text { acetaminophen i.v. }\end{array}$ & Not mentioned & 9 \\
\hline \multirow[t]{9}{*}{ Bevacizumab } & $\begin{array}{c}\text { Suggested infusion rate: } \mathbf{5 - 7 . 5} \mathbf{~ m g} / \mathbf{k g} \\
\text { in } 10 \mathrm{~min}, \mathbf{1 0 - 1 5} \mathbf{~ m g} / \mathbf{k g} \text { in } \mathbf{2 0} \mathbf{~ m i n} \\
\text { First dose }(5-15 \mathrm{mg} / \mathrm{kg}) \\
\text { during } 90 \mathrm{~min}, \text { second dose } \\
\text { during } 60 \mathrm{~min} \text {, all subsequent } \\
\text { doses in } 30 \mathrm{~min} .\end{array}$ & Often $(\geq 1 / 100,<1 / 10)$, up to $5 \%$. & Not necessary & Not specified & 10 \\
\hline & $\begin{array}{l}\text { All doses of } 5 \mathrm{mg} / \mathrm{kg} \\
\text { in } 0.5 \mathrm{mg} / \mathrm{kg} / \mathrm{min}\end{array}$ & $\begin{array}{l}1.6 \% \text { (All classified } \\
\text { as nonserious) }\end{array}$ & $\begin{array}{l}\text { Mentioned only when } \\
\text { the patient had a } \\
\text { reaction on previous } \\
\text { bevacizumab admissions }\end{array}$ & Not mentioned & 11 \\
\hline & $\begin{array}{l}\text { All doses of } 7.5 \mathrm{mg} / \mathrm{kg} \\
\text { in } 0.75 \mathrm{mg} / \mathrm{kg} / \mathrm{min}\end{array}$ & $\begin{array}{l}\text { No statistical differences } \\
\text { in toxicities between } \\
0.75 \mathrm{mg} / \mathrm{kg} / \mathrm{min} \text { and the } \\
\text { conventional dosing } \\
\text { (90-60-30-min regime) }\end{array}$ & Antihistamine & Not mentioned & 12 \\
\hline & $\begin{array}{c}\text { All doses of } 5 \mathrm{mg} / \mathrm{kg} \\
\text { and } 7.5 \mathrm{mg} / \mathrm{kg} \text { in } 10 \mathrm{~min} \\
\text { in metastatic colorectal cancer }\end{array}$ & 2 Grade 2 infusion reactions in 527 dose & es Not mentioned & Not mentioned & 14 \\
\hline & $0.5 \mathrm{mg} / \mathrm{kg} / \mathrm{min}$ & $\begin{array}{l}\text { Shorter bevacizumab infusions } \\
(0.5 \mathrm{mg} / \mathrm{kg} / \mathrm{min}) \text { do not increase the } \\
\text { risk of proteinuria and hypertension }\end{array}$ & Not mentioned & Not mentioned & 15 \\
\hline & $\begin{array}{l}5 \mathrm{mg} / \mathrm{kg}, 7.5 \mathrm{mg} / \mathrm{kg}, 10 \mathrm{mg} / \mathrm{kg} \\
\text { or } 15 \mathrm{mg} / \mathrm{kg} \text { in } 30 \mathrm{~min}\end{array}$ & None reported & $\begin{array}{l}\text { Ranitidine, } 45.5 \mathrm{mg} \\
\text { pheniramine maleate and } \\
8 \mathrm{mg} \text { dexamethasone }\end{array}$ & Not mentioned & 16 \\
\hline & $\begin{array}{l}10 \mathrm{mg} / \mathrm{kg} \text {, First dose in } 90 \mathrm{~min} \\
\text { following doses in } 60 \mathrm{~min} \text { and } \\
30 \mathrm{~min} \text {, as tolerated }\end{array}$ & No HSR were reported & Optional & Not mentioned & 68 \\
\hline & $5 \mathrm{mg} / \mathrm{kg}$ or $7.5 \mathrm{mg} / \mathrm{kg}$ in $30-90 \mathrm{~min}$ & No HSR were reported & Not mentioned & Not mentioned & 69 \\
\hline & $\begin{array}{l}0.5 \mathrm{mg} / \mathrm{kg} / \mathrm{min} \text { From the } \\
\text { first infusion }\end{array}$ & $\begin{array}{l}1 \text { Mild grade } 1 \mathrm{HSR} / 73 \\
\text { infusions ( } 73 \text { patients) }\end{array}$ & Not mentioned & Not mentioned & 13 \\
\hline Blinatumomab & $\begin{array}{l}\text { Philadelphia chromosome- } \\
\text { negative relapsed or } \\
\text { refractory B-precursor } \\
\text { ALL (greater than } 45 \mathrm{~kg} \text { ) } \\
\text { Day 1-7 (cycle } 1 \text { ): } 9 \mu \mathrm{g} / \text { day } \\
\text { continuous infusion } \\
\text { Day } 8-28 \text { (cycle } 1 \text { ): } 28 \mu \mathrm{g} / \text { day } \\
\text { continuous infusion } \\
\text { Day 1-28 (cycle } 1+\text { ): } 28 \mu \mathrm{g} / \text { day } \\
\text { continuous infusion } \\
\text { MRD-positive precursor-B } \\
\text { ALL (greater than } 45 \mathrm{~kg} \text { ) } \\
\text { Induction cycle } 1: \\
\text { Day } 1-28: 28 \mu \mathrm{g} / \text { day } \\
\text { Consolidation cycle } 2-4: \\
\text { Day 1-28: } 28 \mu \mathrm{g} / \text { day }\end{array}$ & Precursor B-ALL: $43.4 \%$ & $\begin{array}{l}100 \mathrm{mg} \text { Prednisolone } \\
\text { intravenously or } \\
\text { equivalent should be } \\
\text { dministered. Antipyretics } \\
\text { during the first } \\
48 \mathrm{~h} \text { are recommended. }\end{array}$ & Not mentioned & 70 \\
\hline
\end{tabular}


Table II. Continued

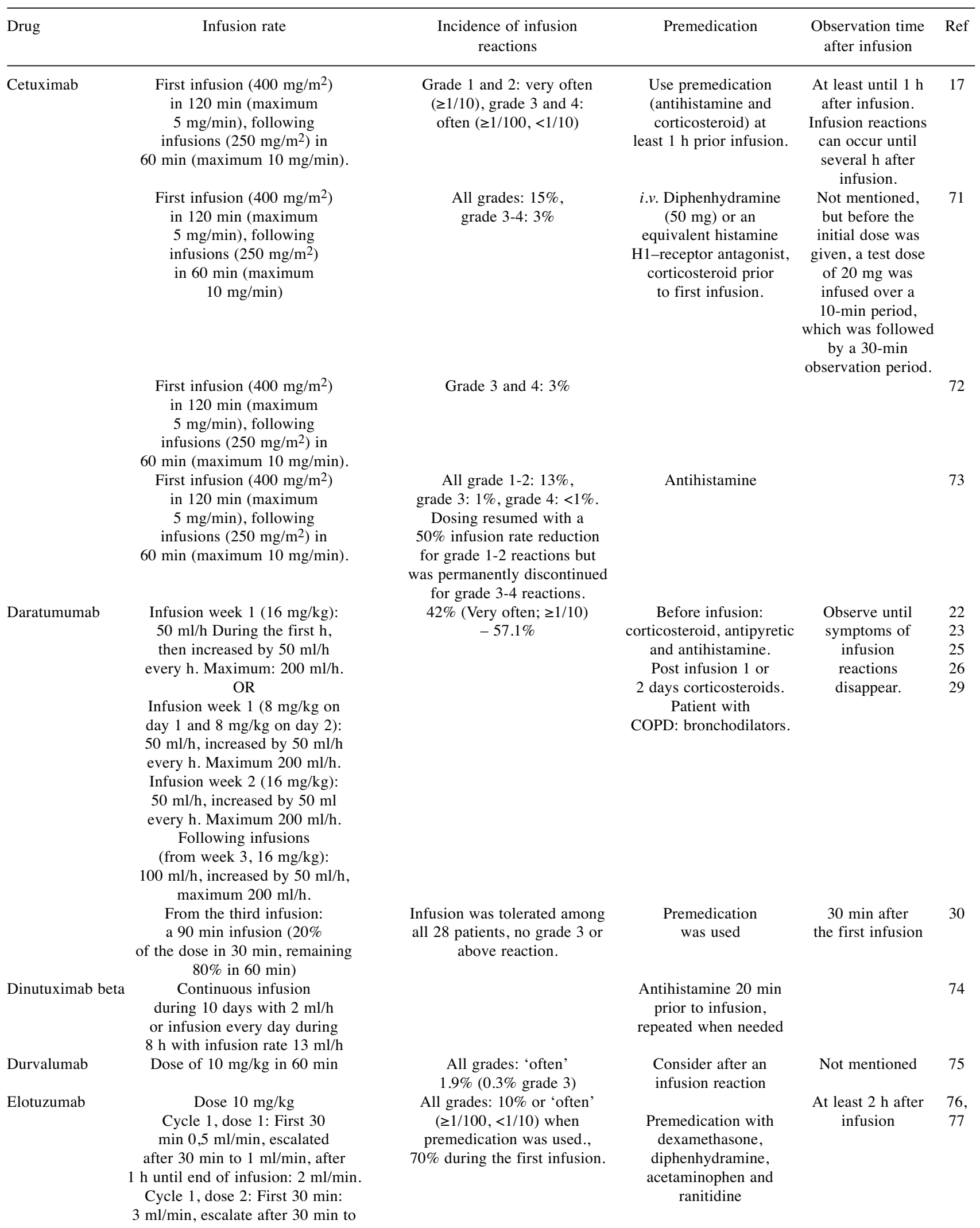


Table II. Continued

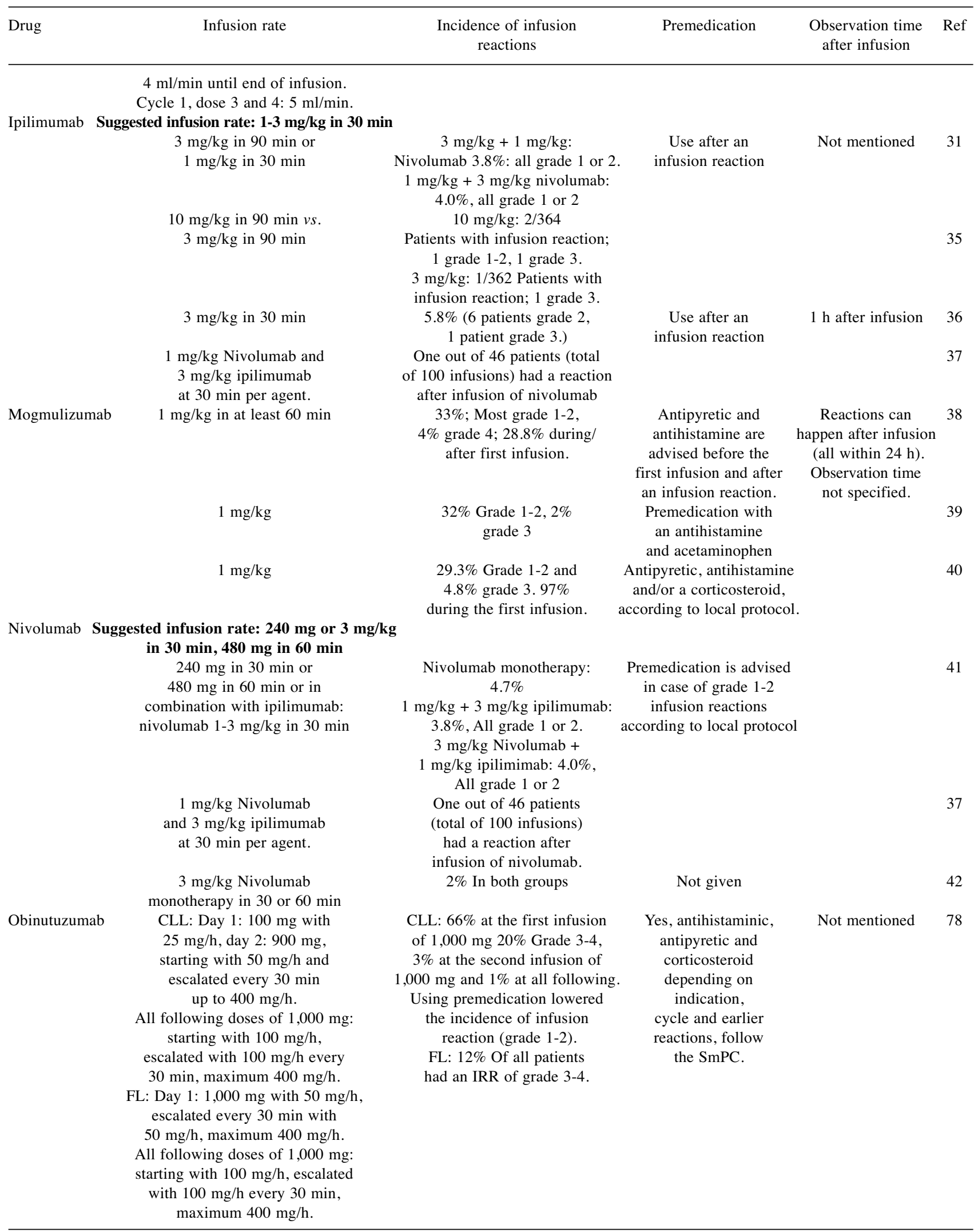


Table II. Continued

\begin{tabular}{|c|c|c|c|c|c|}
\hline Drug & Infusion rate & $\begin{array}{l}\text { Incidence of infusion } \\
\text { reactions }\end{array}$ & Premedication & $\begin{array}{l}\text { Observation time } \\
\text { after infusion }\end{array}$ & Ref \\
\hline \multirow[t]{2}{*}{ Ofatumumab } & $\begin{array}{l}\text { Dosing depends on } \\
\text { indication, see } \mathrm{SmPC} \text {. } \\
\text { First infusion } 12 \mathrm{ml} / \mathrm{h}, \\
\text { increased every } 30 \mathrm{~min} \\
\text { to a maximum of } 400 \mathrm{ml} / \mathrm{h} \text {. } \\
\text { First and second infusion } \\
\text { for refractory CLL had } \\
\text { a maximum of } 200 \mathrm{ml} \text {. } \\
\text { All following: } 25 \mathrm{ml} / \mathrm{h} \text {, } \\
\text { increasing every } 30 \mathrm{~min} \\
\text { to a maximum of } 400 \mathrm{ml} / \mathrm{h}\end{array}$ & $\begin{array}{c}61 \% \text { At any time during } \\
\text { treatment. The majority } \\
\text { of IRRs were grade } 1 \\
\text { or grade } 2.7 \% \geq \text { grade } 3 . \\
\text { No fatal IRRs. }\end{array}$ & $\begin{array}{l}\text { Acetaminophen, an } \\
\text { antihistamine and } \\
\text { an i.v. glucocorticoid }\end{array}$ & & 43 \\
\hline & Treatment according to SmPC. & $\begin{array}{l}\text { Infusion reactions occurred } \\
\text { in } 42 \% \text { of patients in the } \\
\text { ofatumumab arm. } \geq \text { Grade } 3 \\
\text { infusion reaction in } 5 \% \text { (none fatal). }\end{array}$ & $\begin{array}{l}\text { Treatment according } \\
\text { to SmPC. }\end{array}$ & & 44 \\
\hline \multirow[t]{6}{*}{ Panitumumab $\mathbf{S}$} & $\begin{array}{l}\text { Suggested infusion rate: First infusion } \\
\text { in } 60 \mathrm{~min} \text {, second in } 30 \mathrm{~min}, \\
\text { all following in } 15 \mathrm{~min}\end{array}$ & & & & \\
\hline & $\begin{array}{l}\leq 1,000 \mathrm{mg}: \text { First dose in } 60 \mathrm{~min} \\
\text { all following in } 30-60 \mathrm{~min} . \\
>1,000 \mathrm{mg}: \text { All dose in } 90 \mathrm{~min}\end{array}$ & All grades: $5 \%$, grade $3-4: 1 \%$ & Not mentioned & $\begin{array}{l}\text { Not mentioned, } \\
\text { but reactions } \\
>24 \text { h can occur. }\end{array}$ & 45 \\
\hline & $\begin{array}{l}\text { <1,000 mg: First dose in } \\
60 \mathrm{~min}, \text { all following in } 30-60 \mathrm{~min} . \\
>1,000 \mathrm{mg} \text { : All dose in } 90 \mathrm{~min}\end{array}$ & $\begin{array}{c}\text { All grades: } 1.5 \% \\
\text { Grade 3: } 0.2 \% \\
\text { Grade 4: None. } \\
\text { 61.7\% During the first } \\
\text { infusion, } 14.9 \% \text { at the } \\
\text { second, remaining } \\
\text { at third or later. } \\
\text { After infusion reaction } \\
\text { on cetuximab and } \\
\text { with premedication: } \\
\text { 2.8\% Grade 1 }\end{array}$ & $\begin{array}{l}\text { Only given when the } \\
\text { patient had an infusion } \\
\text { reaction on cetuximab }\end{array}$ & & 46 \\
\hline & $\begin{array}{l}6 \mathrm{mg} / \mathrm{kg} \text { Every } 2 \text { weeks: First } \\
\text { dose in } 60 \mathrm{~min} \text {, all following } \\
\text { in } 30-60 \mathrm{~min} \text { or } 9 \mathrm{mg} / \mathrm{kg} \text { every } \\
3 \text { weeks: all dose in } 60 \mathrm{~min}\end{array}$ & $\begin{array}{l}1 \% \text { but none of these were } \\
\text { a reason to stop therapy }\end{array}$ & & & 47 \\
\hline & $\begin{array}{l}6 \mathrm{mg} / \mathrm{kg} \text { in } 60 \text {-min for the } \\
\text { first infusion, followed by a } \\
\text { 30-min infusion, and } 15 \text {-min } \\
\text { infusions thereafter. }\end{array}$ & No IRRs were noted & & & 48 \\
\hline & $\begin{array}{l}6 \mathrm{mg} / \mathrm{kg} \text {, Administration } \\
\text { according to product label }\end{array}$ & grade $1-2: 3 \%$, grade $3:<0.5 \%$. & Not given & & 73 \\
\hline Pembrolizumab & $200 \mathrm{mg}$ and $400 \mathrm{mg}$ in $30 \mathrm{~min}$. & Often $(\geq 1 / 100,<1 / 10)$ & $\begin{array}{l}\text { If grade } 1 \text { or } 2 \text { infusion } \\
\text { reaction, antipyretic } \\
\text { and antihistaminic } \\
\text { premedication should } \\
\text { be considered. Use of } \\
\text { corticosteroids } \\
\text { is discouraged. }\end{array}$ & Not mentioned & 79 \\
\hline Pertuzumab & $\begin{array}{l}\text { First dose }(840 \mathrm{mg}) \\
\text { in } 60 \mathrm{~min} \text {, all following } \\
(420 \mathrm{mg}) \text { in } 30-60 \mathrm{~min} .\end{array}$ & $\begin{array}{l}13.2 \% \text { During first infusion } \\
\text { and } 18.6-25.0 \% \text { during } \\
\text { first infusion (when } \\
\text { combined with trastuzumab } \\
\text { and chemotherapy) }\end{array}$ & $\begin{array}{l}\text { Not mentioned } \\
\text { in the SmPC }\end{array}$ & $\begin{array}{l}\text { First dose at least } \\
60 \text { min, all } \\
\text { following } \\
30-60 \mathrm{~min} .\end{array}$ & 80 \\
\hline Ramucirumab & $\begin{array}{c}\text { Dosing depends on } \\
\text { indication, time of infusion } \\
\text { not more than } \\
25 \mathrm{mg} / \mathrm{min}(\text { around } 1 \mathrm{~h})\end{array}$ & $\begin{array}{l}\text { Infusion reactions were } \\
\text { seen in clinical trials }\end{array}$ & $\begin{array}{l}\text { Antihistamine before } \\
\text { infusion. If a infusion } \\
\text { reaction grade } 1-2 \\
\text { occurs give this before } \\
\text { all following infusions. }\end{array}$ & $\begin{array}{l}\text { Observe during } \\
\text { infusion }\end{array}$ & 81 \\
\hline
\end{tabular}


Table II. Continued

\begin{tabular}{lccc}
\hline Drug & Infusion rate & $\begin{array}{c}\text { Incidence of infusion } \\
\text { reactions }\end{array}$ & $\begin{array}{c}\text { Premedication } \\
\text { Observation time } \\
\text { after infusion }\end{array}$ \\
\hline
\end{tabular}

\footnotetext{
When a second infusion reaction grade 1-2 occurs, give dexamethasone and give before the next infusion an intravenous antihistamine, paracetamol and dexamethasone
}

\section{Rituximab*

\begin{abstract}
Suggested infusion rate: First cycle: Incremental
\end{abstract} scheme from SmPC. \\ Following infusions in $60 \mathrm{~min}$. Use premedication. \\ First infusion: $50 \mathrm{mg} / \mathrm{h}$, increase every $30 \mathrm{~min}$ with $50 \mathrm{mg} / \mathrm{h}$, maximum $400 \mathrm{mg} / \mathrm{h}$. All following infusions: $100 \mathrm{mg} / \mathrm{h}$, increase every $30 \mathrm{~min}$ with \\ $100 \mathrm{mg} / \mathrm{h}$, maximum $400 \mathrm{mg} / \mathrm{h}$.}

NHL: First infusion according to manufacturer's recommendation. Following infusions in $90 \mathrm{~min}, 20 \%$ of the dose during the first $30 \mathrm{~min}$, $80 \%$ during remaining time.

NHL: First infusion according to manufacturer's recommendation. Following infusions in $90 \mathrm{~min}$, $20 \%$ of the dose during the first 30 min, $80 \%$ during remaining time. First infusion according to manufacturer's recommendation. Following infusions in $90 \mathrm{~min}$,

$20 \%$ of the dose during the first $30 \mathrm{~min}$, $80 \%$ during remaining time. First infusion according to manufacturer's recommendation. Following infusions in $90 \mathrm{~min}$, $20 \%$ of the dose during the first $30 \mathrm{~min}$, $80 \%$ during remaining time. NHL: First infusion according to manufacturer's recommendation. Following infusions in $90 \mathrm{~min}$, $20 \%$ of the dose during the first $30 \mathrm{~min}$, $80 \%$ during remaining time.

Second and following infusions in $60 \mathrm{~min}$ with a constant rate

Second and following infusions in 60 min with a constant rate

First cycle: $10 \mathrm{ml} / \mathrm{h}$ (first $1 \mathrm{~h}$ ) $>50 \mathrm{ml} / \mathrm{h}$ (second $1 \mathrm{~h})>100 \mathrm{ml} / \mathrm{h}$ (until end of treatment).

Following infusions depending on cohort: range $50-300 \mathrm{ml} / \mathrm{h}$ (constant infusion until end of treatment) $(<700 \mathrm{mg} / \mathrm{h})$.
No grade 3-4 adverse events. $2.3 \%$ Grade 1 .

No grade 3-4 adverse events. 4/79 Patients, 269 cycles: 1 grade 1 IRR,

3 nausea/vomiting 0/17 Patients, 73 infusions

No grade 3-4 adverse events. Three grade 1 adverse events/319 infusions

(70 patients) (all adverse events)

No grade 3-4 infusion reactions.

0/105 Infusions (54 patients)

5 Grade 1/223 infusions, 0 Grade 3-4/223 infusions (40 patients)

No grade 2-4 adverse events. $22 \%$ grade 1 infusion-related toxicities.

Antipyretic and antihistamine, Not mentioned if corticosteroids are not given with chemotherapy then corticosteroids should be considered. CLL-Patients with lymphocytes $>25 \times 10^{9} / 1$ should be given $100 \mathrm{mg}$ prednisone/prednisolone
1,000 mg Paracetamol p.o., hydroxyzine
30 min after infusion $20 \mathrm{mg}, 67 \%$ of the infusions were given with the corticosteroid.

1,000 mg Paracetamol p.o., Not mentioned diphenhydramine $25 \mathrm{mg}$, corticosteroid when part of the chemotherapy (but after rituximab)

1,000 mg Acetaminophen p.o., Not mentioned $10 \mathrm{mg}$ chlorphenamine i.v., $100 \mathrm{mg}$ hydrocortisone i.v. 82

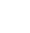


Table II. Continued

\begin{tabular}{|c|c|c|c|c|c|}
\hline Drug & Infusion rate & $\begin{array}{l}\text { Incidence of infusion } \\
\text { reactions }\end{array}$ & Premedication & $\begin{array}{l}\text { Observation time } \\
\text { after infusion }\end{array}$ & Ref \\
\hline & $\begin{array}{l}\text { Depending on cohort, with } \\
\text { a maximum of } 700 \mathrm{mg} / \mathrm{h}\end{array}$ & $\begin{array}{l}\text { No grade } 3-4 \text { adverse } \\
\text { events were seen. Some } \\
\text { grade } 1-2 \text { events. }\end{array}$ & Clemastine and paracetamol & & 87 \\
\hline Siltuximab & $11 \mathrm{mg} / \mathrm{kg}$ in $60 \mathrm{~min}$ & $\begin{array}{c}\text { In clinical trials: } 5.1 \% \\
(0.8 \% \text { was classified as severe }) \\
\text { after long term treatment: } \\
6.3 \%(1.3 \% \text { classified as severe })\end{array}$ & $\begin{array}{l}\text { Can be considered after } \\
\text { an infusion reaction }\end{array}$ & Not mentioned & 88 \\
\hline \multirow[t]{12}{*}{ Trastuzumab } & $\begin{array}{l}\text { First infusion in } 90 \mathrm{~min} \text {, } \\
\text { following in } 30 \mathrm{~min}\end{array}$ & $40 \%$ & $\begin{array}{l}\text { Can be used to prevent an } \\
\text { infusion reaction }\end{array}$ & $\begin{array}{l}6 \mathrm{~h} \text { after the } \\
\text { first infusion, } 2 \mathrm{~h} \\
\text { after the following. }\end{array}$ & 55 \\
\hline & $\begin{array}{l}\text { First infusion in } 90 \mathrm{~min}, \\
\text { following in } 30 \mathrm{~min}\end{array}$ & $\begin{array}{l}16.2 \% \text { Of patients, } \\
1.8 \% \text { of the doses }\end{array}$ & \multirow{2}{*}{\multicolumn{2}{|c|}{$\begin{array}{l}\text { Given when recommended } \\
\text { with chemotherapy } \\
66 \% \text { No premedication, } \\
\text { if premedication was used: } \\
100 \mathrm{mg} \text { hydrocortisone } i . v \text {. and } \\
10 \mathrm{mg} \text { chlorpheniramine. }\end{array}$}} & 56 \\
\hline & $\begin{array}{l}\text { All maintenance doses } \\
\text { were given in } 30 \mathrm{~min}\end{array}$ & $\begin{array}{l}1.5 \% \text { Of all infusions, } \\
3.5 \% \text { of the patients }\end{array}$ & & & 58 \\
\hline & $\begin{array}{l}\text { First dose }(8 \mathrm{mg} / \mathrm{kg}) \text { in } 90 \mathrm{~min} \text {, } \\
\text { following infusion }(6 \mathrm{mg} / \mathrm{kg}) \text { in } 30 \mathrm{~min}\end{array}$ & $26 \%$ & \multicolumn{2}{|l|}{$\begin{array}{l}4 \mathrm{mg} \text { Chlorpheniramine and/or } \\
100 \mathrm{mg} \text { hydrocortisone or } \\
5 \mathrm{mg} \text { dexamethasone } i . v \text {. }\end{array}$} & 60 \\
\hline & $\begin{array}{l}8 \mathrm{mg} / \mathrm{kg} \text { in } 250 \mathrm{ml} \text { over } 90 \mathrm{~min} \text { followed } \\
\text { by } 6 \mathrm{mg} / \mathrm{kg} \text { in } 100 \mathrm{ml} \text { over } 30 \mathrm{~min}\end{array}$ & $\begin{array}{l}6.5 \% \text { Grade } 2 \text { reaction } \\
\text { during the first dose, } \\
0 \% \text { in following doses. }\end{array}$ & Not mentioned & Not mentioned & 59 \\
\hline & $\begin{array}{l}\text { After run-in chemotherapy } \\
\text { and surgery: First infusion of } \\
\text { neoadjuvant treatment: ABP }\end{array}$ & $\begin{array}{c}\text { Neoadjuvant treatment: } \\
\text { ABP 980: } 20 \% \text { Grade } 1-2, \\
2 \% \text { grade } 3 .\end{array}$ & Not mentioned & $\begin{array}{l}6 \mathrm{~h} \text { after first } \\
\text { infusion, } 2 \mathrm{~h} \\
\text { after the following. }\end{array}$ & 89 \\
\hline & 980 or trastuzumab in $90 \mathrm{~min}$. & Trastuzumab: $17 \%$ grade & & & \\
\hline & Following infusions: $6 \mathrm{mg} / \mathrm{kg}$ & $1-2,2 \%$ grade 3 & & & \\
\hline & $\begin{array}{l}\text { ABP } 980 \text { or trastuzumab in } 30 \text { min. } \\
\text { Adjuvant treatment depending }\end{array}$ & $\begin{array}{l}\text { Adjuvant treatment: } \\
\text { ABP 98: } 8 \% \text { Grade }\end{array}$ & & & \\
\hline & $\begin{array}{c}\text { on cohort (ABP 980/trastuzumab/ } \\
\text { switch to ABP } 980 \\
6 \mathrm{mg} / \mathrm{kg} \text { ) in } 30 \mathrm{~min} \text {. }\end{array}$ & $\begin{array}{l}\text { 1-2, } 1 \% \text { grade } 3 . \\
\text { Trastuzumab: } 7 \% \text { Grade } 1-2, \\
1 \% \text { grade } 3 . \text { Switch from } \\
\text { adjuvant trastuzumab to } \\
\text { ABP } 980: 10 \% \text { Grade } 1-2, \\
1 \% \text { grade } 3 \% \text { grade } 4 .\end{array}$ & & & \\
\hline & $\begin{array}{l}\text { Loading dose of } 8 \mathrm{mg} / \mathrm{kg} \text {, followed by } \\
6 \mathrm{mg} / \mathrm{kg} \text { every } 3 \text { weeks given in } 30 \mathrm{~min} \text {. }\end{array}$ & $\begin{array}{l}45 \% \text { During first infusion, } \\
29 \% \text { during second } \\
\text { infusion and } 20 \% \text { during } \\
\text { the third. Only } 3 / 105 \text { had } \\
\text { a serious IRR. }\end{array}$ & $\begin{array}{l}\text { Acetaminophen and } \\
\text { diphenhydramine were } \\
\text { given to patients } \\
\text { at increased risk }\end{array}$ & & 57 \\
\hline & $\begin{array}{l}\text { First dose: } 8 \mathrm{mg} / \mathrm{kg} \text { in } 90 \mathrm{~min} \text { for } \\
\text { the first dose. All following doses: } \\
66 \mathrm{mg} / \mathrm{kg} \text { in } 60 \mathrm{~min} \text {. }\end{array}$ & Five out of 31 patients & $\begin{array}{l}8 \mathrm{mg} \text { Dexamethasone } \\
\text { i.v. for at least the } \\
\text { first three doses }\end{array}$ & Not mentioned & 90 \\
\hline
\end{tabular}

ABP 980: Biosilimar of trastuzumab; HSR: hypersensitivity reaction; ALL: acute lymphoblastic leukemia; MRD: minimal residual disease; CLL: chronic lymphocytic leukemia; FL: follicular lymphoma; i.v.: intravenous; p.o.: per os; SmPC: summary of product characteristics; NHL: nonHodgkin's lymphoma, IRR: infusion-related reaction. *For NHL/CLL; for rheumatoid arthritis there is alternative schedule and incidence of infusion reactions, which is outside of the scope of this article, see also the SmPC of rituximab (49). Bold denotes suggested infusion rates.

of onset of the infusion-related reaction depends on the type of reaction. If the reaction happens within the first minute of infusion, it can be an anaphylactic reaction, induced by antibodies to $\mathrm{IgE}$ which cross-react with cetuximab. The possibility of restarting therapy after an allergic reaction depends on the grade of the reaction and the chance of the presence of $\mathrm{IgE}$ antibodies. If the infusion-related reaction happens after $1 \mathrm{~h}$, it is more likely that the reaction is induced by CRS. Infusion-related reactions can occur during or after the first and subsequent infusions but most and most severe reactions occur during the first infusion (17). Much research has been carried out on infusion-related reactions to 
cetuximab. Most research supports the incidence stated by the manufacturer, but interestingly, a higher number of infusion reactions has been found in the southeastern part of the United States (19). Presumably, this is a result of being bitten by specific ticks in this region, after which serum of these persons contained antibodies against the oligosaccharide galactose-alpha-1,3 galactose (20). This is the same oligosaccharide as present on the Fab portion of the cetuximab heavy chain. Panitumumab also targets EGFR but does not contain galactose-alpha-1,3 galactose. This might well explain the lack of cross-reactivity between cetuximab and panitumumab (21).

According to the manufacturer, the first dose of cetuximab must be preceded by an antihistaminic and a corticosteroid. This premedication is optional for subsequent infusions, provided that no reaction occurred during the first cycle. In theory, patients who have received several cycles of cetuximab without any reaction should be able to tolerate a higher infusion reaction, as well as a shorter observation period. As yet, there are no clinical data available, however, that support such an approach.

Daratumumab. Although daratumumab is a fully human antibody directed against CD38, it is associated with a relatively high incidence of infusion-related reactions. In the phase III trials leading to its registration, almost half of patients (42-48\%) experienced an infusion reaction, of which the majority $(>90 \%)$ occurred at the first infusion $(22,23)$. Infusion reaction symptoms of daratumumab typically include nasal congestion, throat irritation, cough, chills and nausea and vomiting (grade 1-2 in $90-95 \%$ of cases) or bronchospasms, dyspnea, laryngeal and pulmonary edema, hypoxia and hypertension (grade 3 in 5-10\% of cases) $(22,23)$. Only $7 \%$ of patients experienced infusion reactions starting at the second or third dose and only $5 \%$ had reactions in more than one cycle (24). Infusion reactions can be managed rather easily by interruption of the infusion, treatment with standard rescue medication such as antihistamines or bronchodilators, and restarting at half of the infusion rate after complete recovery from the symptoms (25). Several approaches to reducing the incidence of infusion-related reactions are mandatory as prescribed by the manufacturer, including i) an incremental infusion rate for the first, second and third infusions; ii) diluting the first dose into $1,000 \mathrm{ml}$ versus 500 $\mathrm{ml}$ for subsequent doses; iii) pre-treatment with corticosteroids, antipyretics and antihistamines; and iv) posttreatment administration of corticosteroids (25). Following market introduction, a small but significant reduction of infusion reactions was observed when montelukast was added to the premedication (26), or when the first dose was split over 2 consecutive days (27). There is not much data on the occurrence of late-onset infusion reactions, which could be used to establish an evidence-based observation time post infusion. The median time to onset of a reaction is $1.4 \mathrm{~h}$ according to the manufacturer (25), which is well within the range of infusion since the first cycle should be given over a minimum of 6.5 hours. An Australian expert panel of myeloma nurses suggested a 2-h observation time after the first cycle (28). In addition, patients with a history of severe chronic obstructive pulmonary disease or asthma should receive extra monitoring and be considered for extra postinfusion inhaled medications (corticosteroids and short- and long-acting bronchodilators) (29). Despite the high rate of infusion reactions, one study group in Ohio performed a small open trial on acceleration of the infusion after patients had received two or more doses in $500 \mathrm{ml}$ at the standard infusion rate without complications. In 28 patients, reducing the administration time to $90 \mathrm{~min}$ was found to be safe. Notably in this trial, famotidine was added to the premedication regimen but when doses were tolerated, the premedication was limited to dexamethasone only (30). The results of this study were promising, but ideally should be confirmed in a larger trial before definite recommendations to increase the infusion rate for the overall population can be made.

Ipilimumab. Ipilimumab is a fully human monoclonal antibody directed against the cytotoxic T-lymphocyte antigen-4. Its first registration was for monotherapy at 3 $\mathrm{mg} / \mathrm{kg}$ in patients with metastatic melanoma, followed by combination therapy of $3 \mathrm{mg} / \mathrm{kg}$ with nivolumab $(1 \mathrm{mg} / \mathrm{kg})$ for melanoma, and combination at $1 \mathrm{mg} / \mathrm{kg}$ with nivolumab $(3 \mathrm{mg} / \mathrm{kg}$ ) for renal cell carcinoma. The licensed infusion duration is $90 \mathrm{~min}$ for $3 \mathrm{mg} / \mathrm{kg}$, and $30 \mathrm{~min}$ for $1 \mathrm{mg} / \mathrm{kg}$ (31). The landmark clinical trials with ipilimumab in melanoma ( $3 \mathrm{mg} / \mathrm{kg}$ ) include the Checkmate as well as the Keynote studies, which showed infusion-related reactions in 0.6-4.1\% of patients (32-34). A higher dose as well as combination with nivolumab appears to have an association with a slightly higher incidence of infusion reactions. In the NCT01515189 trial on advanced melanoma, $10 \mathrm{mg} / \mathrm{kg}$ ipilimumab infused over $90 \mathrm{~min}$ was compared to $3 \mathrm{mg} / \mathrm{kg}$, also infused over $90 \mathrm{~min}$. In the $10 \mathrm{mg} / \mathrm{kg}$ arm, 2/364 patients experienced an infusion reaction, one being of grade $1-2$, and the other of grade 3 . In the $3 \mathrm{mg} / \mathrm{kg}$ arm, $1 / 362$ patients experienced a grade 3 infusion reaction (35). From these data, where $10 \mathrm{mg} / \mathrm{kg}$ was safely be infused over the same time as $3 \mathrm{mg} / \mathrm{kg}$, the idea came that $3 \mathrm{mg} / \mathrm{kg}$ might also be safely infused at the rate of $1 \mathrm{mg} / \mathrm{kg}$. This concept was prospectively studied in 120 patients receiving ipilimumab at $3 \mathrm{mg} / \mathrm{kg}$ in $30 \mathrm{~min} ; 5.8 \%$ experienced infusion-related reactions (seven patients, of whom six had a grade 2 and one experienced a grade 3 reaction). All reactions occurred at the second dose, which implicates the first dose as a sensitizing cycle. Although the incidence of infusion reactions was slightly higher than seen in the large phase III trials, it was not significantly different from that in patients who were 
given $3 \mathrm{mg} / \mathrm{kg}$ over $90 \mathrm{~min}$ at the same institution (36) Substantiation for safe administration of $3 \mathrm{mg} / \mathrm{kg}$ over 30 min comes from a German study which combined ipilimumab and nivolumab at $30 \mathrm{~min}$ per agent. Forty-six patients received 100 of these rapid cycles and none had a bona fide infusion-related reaction (37). Arguably, if this concept were to be extrapolated to the lowest licensed dose of $1 \mathrm{mg} / \mathrm{kg}$, that might safely be infused in only $10 \mathrm{~min}$. However, as yet, no data for this effect have been presented. Late-onset infusion-related reaction has not been described in the landmark trials, but was observed post marketing in one of the rapid-infusion studies in a single patient at 30-min post infusion. The manufacturer does not prescribe an observation time after infusion (31).

Mogamulizumab. Mogamulizumab is a humanized $\operatorname{IgG} 1 \mathrm{~K}$ specifically targeting CC-chemokine receptor 4. This receptor is usually overexpressed on malignant T-cells. It is licensed in Europe and the USA for the treatment of mycosis fungoides (cutaneous T-cell lymphoma) and Sezary syndrome that is either refractory to or has manifested as a relapse following at least one prior line of treatment (38). In Japan, an additional licensing was launched in 2012 for refractory adult T-cell leukemia-lymphoma, under the condition that a post marketing all-case surveillance study would be conducted. The landmark phase III trial upon which the European registration was granted compared mogamulizumab with vorinostat in cutaneous T-cell lymphoma. In this trial, 58/184 (32\%) patients in the mogamulizumab arm experienced a grade 1 or 2 infusion reaction, and $3 / 184(2 \%)$ had a grade 3 reaction, despite premedication with an antihistamine and acetaminophen. Symptoms consisted of chills, fever, headache, nausea, rigors, tachycardia and vomiting (39). Earlier data, before the introduction of the pre-medication schedule, showed infusion reactions in $42 \%$ of cases. Hence, premedication is able to reduce but not eliminate the occurrence of infusion reactions. The Japanese post-marketing surveillance included 484 patients, and observed infusion-related reactions in $29.3 \%$ (grade 1 or 2) and $4.8 \%$ (grade 3 ) of patients, respectively. All but one patient received premedication with an antipyretic, antihistaminic/corticosteroid, according to local protocol. When comparing the group which received a corticosteroid with the group which did not, reactions in $27.5 \%$ and $35 \%$, respectively, were reported, indicating that adding a corticosteroid to the premedication regime has an additional effect but still does not eliminate the incidence of infusion-related reactions; $97 \%$ of the patients who experienced an infusion reaction, did so in the first course of their mogamulizumab treatment (40).

Nivolumab. Nivolumab, a human immunoglobulin G4 monoclonal antibody to the programmed death-1 receptor, is registered as monotherapy for melanoma (also as adjuvant therapy), non-small cell lung cancer, renal cell carcinoma, classical Hodgkin lymphoma, squamous cell cancer of the head and neck and urothelial carcinoma, and in combination with ipilimumab in the treatment of melanoma and renal cell carcinoma. According to the SmPC, nivolumab is given at an infusion rate of $240 \mathrm{mg}$ in $30 \mathrm{~min}$ or $480 \mathrm{mg}$ in $60 \mathrm{~min}$. Nivolumab combined with ipilimumab is given in $1-3 \mathrm{mg} / \mathrm{kg}$ in $30 \mathrm{~min}$ (41). The SmPC states that in $<1 \%$ of the patients, a grade 3 or 4 treatment-related hypersensitivity or infusion reaction was found to lead to treatment discontinuation (41). To read more about the infusion reaction in dual monoclonal antibody therapy, please also see the section on 'ipilimumab'. In 2018, Waterhouse et al. investigated monotherapy nivolumab $3 \mathrm{mg} / \mathrm{kg}$ for advanced non-small cell lung cancer to see whether this dose could be safely given in $30 \mathrm{~min}$ instead of $60 \mathrm{~min}$. In both groups, an incidence of $2 \%$ hypersensitivity or infusionrelated reactions was seen, leading to the conclusion that an infusion time of $30 \mathrm{~min}$ is safe (42). As yet, no data on faster infusion of the high dose of $480 \mathrm{mg}$ have been published.

Ofatumumab. Ofatumumab is a fully human monoclonal antibody specifically targeting CD20. It is used in combination with fludarabine and cyclophosphamide for relapsed chronic lymphocyte leukemia (CLL) or in combination with bendamustin and chlorambucil for newly diagnosed CLL. Ofatumumab binds to a specific epitope comprising both the small and the large loops of CD20. It has activity, among others, in rituximab-resistant B-cell lymphocytes. Although fully human, ofatumumab administration results in a very high incidence of infusion-related reactions which are potentially fatal (43). These reactions occur in $42-44 \%$ of patients during the first cycle (which consists of a low dose of $300 \mathrm{mg}$, preceded by acetaminophen, an antihistamine and intravenous glucocorticoid) and in $29 \%$ during the second cycle $(43,44)$. The symptoms of infusion reaction with ofatumumab are transient rigors, pyrexia, fatigue, rash, and increased sweating (mild), but can also be more severe, including bronchospasms, dyspnea, laryngeal and pulmonary edema, hypertension and hypotension, syncope, back pain, urticaria and angioedema (43). Because of this high incidence of infusion reactions, all measures to avoid these should be used in ofatumumab treatment (43). Firstly, all patients should be treated with adequate premedication consisting of acetaminophen, an antihistamine and intravenous glucocorticoid. Secondly, the first infusion must always be a reduced dose. Thirdly, slow increment of the infusion rate is prescribed, starting at 12 $\mathrm{ml} / \mathrm{h}$; if no reaction occurs, the rate of infusion can be increased stepwise to a maximum of $200 \mathrm{ml} / \mathrm{h}$ every $30 \mathrm{~min}$. In addition, the second infusion, at full dose, should again start at the low rate of $12 \mathrm{ml} / \mathrm{h}$. Subsequent cycles still require stepwise infusion rate titration but can start at $25 \mathrm{ml} / \mathrm{h}$ if no complication has been observed previously. From the 
published study data, there appear to be no delayed infusion reactions with ofatumumab, therefore a clinical observation time after the end of a cycle when no events were noted during the administration appears unnecessary.

Panitumumab. Panitumumab is an EGFR-directed fully human IgG2 monoclonal antibody, derived using a different cell culture technique from that for cetuximab. In contrast to cetuximab, the panitumumab molecule does not hold galactose 1,3-alpha galactose on the Fab fragment. The licensed infusion instructions state that the first infusion should be given in 60 min, and subsequent infusions can be administered in $30 \mathrm{~min}$ if the first cycle was well tolerated. However, doses of over 1,000 $\mathrm{mg}$ should always be administered in $90 \mathrm{~min}$. The SmPC also combined all phase II and III studies (total of 2,224 patients) to evaluate the rate of infusion reactions. These totaled to $5 \%$, and $1 \%$ were grade 3-4 (45). This low rate of reactions was later confirmed in a Japanese post-marketing surveillance study of 3,085 patients, where treatment was administered according to the directions by the manufacturer: 47 patients $(1.5 \%)$ showed an infusion reaction. Grade 3 or serious cases occurred in six out of the 3,085 patients $(0.2 \%)$. No grade 4 reactions were observed. In $61.7 \%$ of cases, the reaction occurred at the first infusion and $14.9 \%$ at the second. The remaining patients had a reaction at the third or later infusion, with the latest reaction occurring at the 21 st administration. In this analysis, 70 patients with a history of infusion reaction to cetuximab received panitumumab. These were treated with premedication and a reduced infusion speed. Two of these 70 patients had a mild infusion reaction (grade 1), while none had a severe reaction (46). Two trials investigating accelerated infusion schemes have been published to date. The first was an open label study investigating two dosing schedules of panitumumab: $6 \mathrm{mg} / \mathrm{kg}$ every 2 weeks, and $9 \mathrm{mg} / \mathrm{kg}$ every 3 weeks. The patients who received the two-weekly schedule, were given the first dose in $60 \mathrm{~min}$, followed by subsequent doses in $30 \mathrm{~min}$ if the first infusion was well tolerated. The patients receiving the higher dose of $9 \mathrm{mg} / \mathrm{kg}$, received all doses in 60-min. In this trial, 68 patients were enrolled, and no infusion reactions were reported. A post-hoc analysis, however, identified five potential infusion reactions, resulting in a $1 \%$ rate of infusion reactions overall, but none of these infusions were stopped nor was therapy withheld because of it. The study concluded that both the 60 $\min 9 \mathrm{mg} / \mathrm{kg}$ as well as the 60 -min followed by $30-\mathrm{min} 6 \mathrm{mg} / \mathrm{kg}$ regimens were safe (47). The second trial included 43 patients who received $6 \mathrm{mg} / \mathrm{kg}$ panitumumab in 60 -min for the first infusion, followed by a 30-min infusion, and 15-min infusions thereafter. Nine patients did not reach the 15-min infusion, mainly due to disease progression. The remaining 34 patients received a total of 187 doses in $15 \mathrm{~min}$. No infusion-related reactions were noted in the entire study, resulting in the investigators' conclusion that the short-infusion regimen was well tolerated and did not compromise safety or efficacy (48).
In conclusion, the differentiation between higher and lower doses ( $>1,000$ and $\leq 1,000 \mathrm{mg}$, respectively), as well as the minimum infusion duration of 30 -min, might both be unnecessarily strict. However, the data published on faster infusions are based on relatively small numbers of patients and a larger cohort of rapid infusion data would be of great value.

Rituximab. Rituximab binds to CD20-positive Blymphocytes, inducing their death and activating an anti-CD20 immunoreaction. Infusion reactions, including CRS, are seen often $[77 \%$ of patients with non-Hodgkin lymphoma (NHL) or CLL], mostly during the first infusion in the first $2 \mathrm{~h}$. During subsequent infusions, the likelihood of an infusion reaction is lower. Around $12 \%$ of these reactions are severe and fatal cases have been reported (49). Symptoms of tumor lysis syndrome and CRS can be seen. Symptoms of a tumor lysis syndrome are hyperuricemia, hyperkaliemia, hypocalcemia, hyperphosphatemia, acute kidney failure and respiratory depression. CRS following rituximab is known for dyspnea, bronchospasm, hypoxia, fever, chills, rigors and angioedema. Patients with bulky disease or $>25 \times 10^{9} / 1$ lymphocytes, mostly patients with CLL, have a higher probability of CRS and should be monitored carefully (49, 50). A lower infusion rate or dividing the dose over 2 days should be considered for these patients.

Rituximab is registered for several different diseases. According to the product information, the infusion rate during the first infusion is the same for all indications (49). However, the infusion rate during the following infusion depends on the indication, since the infusions for rheumatoid arthritis can be faster for most patients because the incidence of infusion reactions in rheumatoid arthritis is lower. The first infusion should always be given with an infusion rate of 50 $\mathrm{mg} / \mathrm{h}$ and can be accelerated up to a maximum of $400 \mathrm{mg} / \mathrm{h}$, increasing by $50 \mathrm{mg} / \mathrm{h}$ every $30 \mathrm{~min}$. According to the manufacturer, all further infusions should be given at the same maximum infusion rate of $400 \mathrm{mg} / \mathrm{h}$ but one can start with an infusion rate of $100 \mathrm{mg} / \mathrm{h}$, accelerating with $100 \mathrm{mg} / \mathrm{h}$ every $30 \mathrm{~min}$. Post-marketing research showed that faster infusion is possible. A meta-analysis of Lang et al. compared 90- and 60-min regimens of rituximab in the treatment of NHL and CLL. During the 90-min infusion, $20 \%$ of the dose was given in the first $30 \mathrm{~min}$ and the remaining dose in the next hour. In the 60-min infusion regimes for NHL studies all doses were given at the same constant infusion rate. All studies that were included in the meta-analysis followed the advice of using premedication (studies that were available in full text are included in Table II). They concluded that the faster regimen is safe for patients with NHL since they saw a low incidence of reactions, which could be due to the high percentage of corticosteroid use and the absence of 'bulky disease' and leukocytosis. Lang et al. warned against rapid 
infusion for patients with CLL since the evidence of their analysis was weak (only a limited number of patients included) (51). The results in CLL looked promising, with a low incidence of adverse reactions. However, more research on fast infusion in this patient group is required.

Premedication with antipyretics and antihistamine are recommended in the SmPC, as well as the use of corticosteroids if they are not already given as part of the chemotherapy. Although several studies did not give corticosteroids as premedication, it is still unclear if this influences the number of infusion reactions $(52,53)$. More research is important since rituximab is also given as monotherapy. When patients with CLL have lymphocytes $>25 \times 10^{9} / 1,100 \mathrm{mg}$ of prednisone/prednisolone should always be given to reduce the chance of a severe infusion reaction or CRS (49). Premedication and a slow first infusion are then common practice. Laudati et al. also suggested priming of the intravenous line, since this gives a lower chance of developing hypersensitivity reaction during the first infusion (35\% in diluent-primed arm versus $19 \%$ in the drug-primed arm) (54).

Trastuzumab. Trastuzumab is a humanized monoclonal antibody used in the treatment of human epidermal growth factor receptor-2 (HER2)-overexpressing cancer. The product specifications recommend the first infusion of trastuzumab be given over $90 \mathrm{~min}$ and, when tolerated, all following infusions in half an hour. Trastuzumab is associated with infusion reactions not only during but also after infusion. The product information reports an incidence of $40 \%$ (55), but numbers vary in literature (see also Table II). Thompson et al. retrospectively investigated the incidence of infusion reactions in clinical practice in patients with breast cancer. They used the same infusion rates as recommended in the product information and gave premedication when this was part of the chemotherapy protocol. Total incidence of infusion reactions was $16.2 \%$ and $91 \%$ of the reactions were seen during the first dose. No grade 3 or 4 reactions were documented (56). Baselga et al. saw an incidence which was almost three-fold higher during the first infusion, although they used an infusion rate of $90 \mathrm{~min}$ for all infusions. The incidence they reported was $45 \%$ during the first infusion, $29 \%$ during the second infusion and $20 \%$ during the third infusion. Baselga et al. explained the higher incidence compared to other trials by the broad definition of infusionrelated reactions that was used (57). Ring et al. reported an infusion reaction incidence of $3.5 \%$ for all patients with 30 min infusion for all maintenance doses (58). Abe et al. investigated whether 30-min infusion of trastuzumab with $100 \mathrm{ml}$ saline from the second dose differed from trastuzumab with $250 \mathrm{ml}$ saline, as is recommended by the product specification. No differences were seen in the incidence of infusion reactions (6.5\% grade 2 reactions) (59).
Trastuzumab is not only used in the treatment of breast cancer but less research has been performed on infusion reactions in other indications. Oh et al. investigated infusion reactions due to trastuzumab infusion combined with chemotherapy in the treatment of HER2-positive gastric cancer. They saw an incidence of $26 \%$ when trastuzumab was infused over $30 \mathrm{~min}$. There were no infusion reactions seen when trastuzumab was given as monotherapy, so it is uncertain if the reactions reported were only due to trastuzumab. Nevertheless, Oh et al. concluded that infusion of trastuzumab in 30 min together with chemotherapy was safe in the treatment of gastric cancer (60).

Most infusion reactions to trastuzumab were classified as grade 1-2 but there are reports of fatal cases (55). Cook et al. reported an incidence of $0.04 \%$ fatal cases according to postmarketing surveillance data (61). Patients have the highest chance of developing an infusion reaction during the first infusion. Moreover, patients who have a reaction during the first hour have the highest chance of having a subsequent serious infusion reaction (61). Analyses of 74 patients experiencing symptoms of a serious infusion-related reaction showed that these patients were suffering from respiratory symptoms (65\%) and chills/rigors (32\%) (61). Patients should be warned of the late signs of an infusion reaction since there are cases which had a delayed infusion reaction up to a week after infusion. Therefore the SmPC recommends that patients should be observed for $6 \mathrm{~h}$ after the first infusion and at least $2 \mathrm{~h}$ after all subsequent ones (55). However, in our practice this is often reduced if a patient shows no hypersensitivity reaction during the first two cycles. Patients with dyspnea due to their malignancy seem to have a higher probability of a fatal infusion reaction and these patients should therefore not receive trastuzumab (55). Thomson et al. also saw a higher incidence of infusion reaction in patients with obesity, probably due to a higher dose of trastuzumab but the underlying reason is not known. A higher maintenance dose was not associated with a higher likelihood of an infusion reaction. The stage of disease, however, was found to be associated with the risk of developing an infusion reaction: Patients with metastatic disease had a significantly higher likelihood of developing an infusion reaction (56).

According to the SmPC, premedication is not recommended but can be used to reduce the chance of an infusion reaction (55). Thomson et al. saw a lower incidence of infusion reactions in patients who used premedication with their chemotherapy. Although this result was not statistically significant $(p=0.065)$, the relevance of using premedication should be investigated more extensively (56). Tanz et al. described two cases of patients with a severe infusion reaction after the first and sixth infusion, who were successfully rechallenged with premedication consisting of antihistamine and corticosteroids and a very low infusion rate (3 and $5 \mathrm{~h}$ instead of $90 \mathrm{~min}$ ) (62). 


\section{Discussion}

Infusion reactions can occur with all monoclonal antibodies. The incidence does not appear to correlate with the origin (human, chimeric or mouse) of the drug, which might be explained by the fact that cytokine release is more often the causative factor than pure IgE-mediated allergy. The data on rituximab, where infusion reactions occur at double the rate in oncology patients when compared to patients with rheumatoid arthritis, supports this hypothesis. For several monoclonal antibodies, different approaches to reduce the incidence of these reactions have been attempted. These include the use of preventative drugs prior to infusion, as well as starting with a lower dose or infusion rate. However, none of these measures can fully eliminate the occurrence of infusion reactions, not even when they are all used in combination. Hence, adequate protocols to manage reactions remain pivotal.

Recently, several monoclonal antibodies in oncology have become available as subcutaneous infusion or injection (trastuzumab and rituximab), while others are currently being evaluated in clinical tests (daratumumab). Pharmacokinetics of subcutaneous administration differ from those of intravenous administration, resulting in a slower increase in serum level of the monoclonal antibody and, as a consequence, in a later and lower maximum concentration (Cmax). If rapid cytokine release is enhanced by a fast and high Cmax, which is to be expected from a pharmacological viewpoint, subcutaneous administration may reduce the incidence as well as the severity of reactions. This has in fact been demonstrated for trastuzumab $(63,64)$ and rituximab $(65$, 66 ), but appears to come at the cost of a substantial number of patients experiencing injection site reactions (63-66).

In order to improve patient satisfaction in combination with reducing hospital drug-delivery related healthcare costs, shortening infusion duration or shortening postadministration observation time is an attractive option. With the ever-increasing number of monoclonal antibodies reaching the market in the field of oncology, this approach is gaining more and more attention. From our review, we conclude that administration of the following monoclonal antibodies in an increased infusion rate as compared to the one stated by the manufacturer is safe: Bevacizumab, ipilimumab, nivolumab (low dose), panitumumab and rituximab. In addition, a shorter observation time for trastuzumab post infusion also seems feasible. For monoclonal antibodies associated with a low incidence of infusion reactions, such as durvalumab and pembrolizumab, a similar approach might be achievable but no data are currently available.

Most monoclonal antibodies are given with premedication (antihistamine, antipyretics and corticosteroids) when they are used in a protocol with chemotherapy in order to reduce the likelihood of side-effects of the treatment such as infusion- related reactions. Moreover, when monoclonal antibodies are given as monotherapy, premedication is used but not always. In order to reduce the risk of an infusion reaction and time in hospital, the relevance of premedication should be investigated to decide which patients benefit from it. In this way, one can make a decision between treating with premedication when needed, or not giving premedication with the benefit of preventing their side-effects.

There are limited post-marketing studies available on infusion reactions and the infusion rate used for administration of monoclonal antibodies. Most studies are relatively small, and since these studies sometimes use different definitions of infusion-related reactions, the apparent incidence can vary. Even fewer studies on post administration observation time have been performed. This makes it challenging to define recommendations. More research is needed on this subject to improve patient satisfaction and to reduce hospital drug delivery-related healthcare costs.

\section{Conflicts of Interest}

No conflicts of interest to be declared.

\section{Authors' Contributions}

MR executed the study, analyzed the findings and prepared the article. ES interpreted and analyzed the results and was involved in the writing of the manuscript. AvdE interpreted and analyzed the results and was involved in the writing of the manuscript. MC designed the study and prepared the article.

\section{References}

1 Lenz HJ: Management and preparedness for infusion and hypersensitivity reactions. Oncologist 12(5): 601-609, 2007. PMID: 17522249. DOI: 10.1634/theoncologist.12-5-601

2 Dillman RO and Hendrix CS: Unique aspects of supportive care using monoclonal antibodies in cancer treatment. Support Cancer Ther 1(1): 38-48, 2003. PMID: 18628130. DOI: 10.3816/SCT.2003.n.003

3 Vogel WH: Infusion reactions: Diagnosis, assessment, and management. Clin J Oncol Nurs 14(2): E10-21, 2010. PMID: 20350882. DOI: 10.1188/10.cjon.e10-e21

4 Breslin S: Cytokine-release syndrome: Overview and nursing implications. Clin J Oncol Nurs 11(1 Suppl): 37-42, 2007. PMID: 17471824. DOI: 10.1188/07.cjon.s1.37-42

5 Common Terminology Criteria for Adverse Events (CTCAE) version 5.0 (2017). U.S. Department of Health and Human Services. Available at: https://ctep.cancer.gov/protocol development/electronic_applications/docs/CTCAE_v5_Quick_R eference_8.5x11.pdf [Last accessed in December 2019]

6 Chung $\mathrm{CH}$ : Managing premedications and the risk for reactions to infusional monoclonal antibody therapy. Oncologist 13(6): 725-732, 2008. PMID: 18586928. DOI: 10.1634/theoncologist. 2008-0012 
7 Picard M and Galvao VR: Current knowledge and management of hypersensitivity reactions to monoclonal antibodies. J Allergy Clin Immunol Pract 5(3): 600-609, 2017. PMID: 28110056. DOI: $10.1016 /$ j.jaip.2016.12.001

8 SmPC Avelumab. European Medicines Agency. Available at: https://www.ema.europa.eu/en/documents/productinformation/bavencio-epar-product-information_nl.pdf [Last accessed in November 2019]

9 Barlesi F, Vansteenkiste J, Spigel D, Ishii H, Garassino M, de Marinis F, Ozguroglu M, Szczesna A, Polychronis A, Uslu R, Krzakowski M, Lee JS, Calabro L, Aren Frontera O, Ellers-Lenz B, Bajars M, Ruisi M and Park K: Avelumab versus docetaxel in patients with platinum-treated advanced non-small-cell lung cancer (JAVELIN Lung 200): An open-label, randomised, phase 3 study. Lancet Oncol 19(11): 1468-1479, 2018. PMID: 30262187. DOI: 10.1016/s1470-2045(18)30673-9

10 SmPC Bevacizumab. European Medicines Agency. Available at: https://www.ema.europa.eu/en/documents/productinformation/avastin-epar-product-information_nl.pdf [Last accessed in September 2019]

11 Reidy DL, Chung KY, Timoney JP, Park VJ, Hollywood E, Sklarin NT, Muller RJ and Saltz LB: Bevacizumab $5 \mathrm{mg} / \mathrm{kg}$ can be infused safely over 10 minutes. J Clin Oncol 25(19): 26912695, 2007. PMID: 17602073. DOI: 10.1200/jco.2006.09.3351

12 Mir O, Alexandre J, Coriat R, Ropert S, Boudou-Rouquette P, Bui T, Chapron J, Durand JP, Dusser D and Goldwasser F: Safety of bevacizumab $7.5 \mathrm{mg} / \mathrm{kg}$ infusion over 10 minutes in NSCLC patients. PMID: 21614447. Invest New Drugs 30(4): 1756-1760, 2012. DOI: 10.1007/s10637-011-9690-9

13 Gil S, Nicolás F, Fuente G, Casariego G, Romero M and López J: Ten-minute administration of bevacizumab. PMID: 31338171 Eur J Hosp Pharm 26, 2017. DOI: 10.1136/ejhpharm-2017001232

14 Mahfoud T, Tanz R, Mesmoudi M, Khmamouche MR, Bazine A, Aassab R, Ismaili N, Boutayeb S, Ichou M and Errihani H: Bevacizumab 5 or $7.5 \mathrm{mg} / \mathrm{kg}$ in metastatic colorectal cancer can be infused safely over 10 minutes. J Gastrointest Cancer 43(2): 244-248, 2012. PMID: 21197622. DOI: 10.1007/s12029-0109245-x

15 Shah SR, Gressett Ussery SM, Dowell JE, Marley E, Liticker J, Arriaga Y and Verma U: Shorter bevacizumab infusions do not increase the incidence of proteinuria and hypertension. Ann Oncol 24(4): 960-965, 2013. PMID: 23175623. DOI: 10.1093/annonc/mds593

16 Yanmaz MT, Guner SI, Satilmis B, Akyol H and Aydin MA: Thirty-minutes infusion rate is safe enough for bevacizumab; no need for initial prolong infusion. Med Oncol 31(11): 276, 2014. PMID: 25294426. DOI: 10.1007/s12032-014-0276-1

17 SmPC Cetuximab. European Medicines Agency. Available at: https://www.ema.europa.eu/en/documents/productinformation/erbitux-epar-product-information_nl.pdf [Last accessed in August 2019]

18 Yamaguchi K, Watanabe T, Satoh T, Ishiguro M, Izawa M, Inoshiri S, Sugihara K and Sakata Y: Severe infusion reactions to cetuximab occur within $1 \mathrm{~h}$ in patients with metastatic colorectal cancer: Results of a nationwide, multicenter, prospective registry study of 2126 patients in Japan. Jpn J Clin Oncol 44(6): 541-546, 2014. PMID: 24771864. DOI: 10.1093/jjco/hyu049

19 Keating K, Walko C, Stephenson B, O'Neil BH and Weiss J: Incidence of cetuximab-related infusion reactions in oncology patients treated at the University Of North Carolina Cancer Hospital. J Oncol Pharm Pract 20(6): 409-416, 2014. PMID: 24243920. DOI: $10.1177 / 1078155213510542$

20 Commins SP, James HR, Kelly LA, Pochan SL, Workman LJ, Perzanowski MS, Kocan KM, Fahy JV, Nganga LW, Ronmark E, Cooper PJ and Platts-Mills TA: The relevance of tick bites to the production of $\mathrm{IgE}$ antibodies to the mammalian oligosaccharide galactose-alpha-1,3-galactose. J Allergy Clin Immunol 127(5): 1286-1293.e1286, 2011. PMID: 21453959. DOI: $10.1016 /$ j.jaci.2011.02.019

21 Langerak A, River G, Mitchell E, Cheema P and Shing M: Panitumumab monotherapy in patients with metastatic colorectal cancer and cetuximab infusion reactions: A series of four case reports. Clin Colorectal Cancer 8(1): 49-54, 2009. PMID: 19203897. DOI: 10.3816/CCC.2009.n.008

22 Lokhorst HM, Plesner T, Laubach JP, Nahi H, Gimsing P, Hansson M, Minnema MC, Lassen U, Krejcik J, Palumbo A, van de Donk NW, Ahmadi T, Khan I, Uhlar CM, Wang J, Sasser AK, Losic N, Lisby S, Basse L, Brun N and Richardson PG: Targeting CD38 with daratumumab monotherapy in multiple myeloma. N Engl J Med 373(13): 1207-1219, 2015. PMID: 26308596. DOI: 10.1056/NEJMoa1506348

23 Dimopoulos MA, San-Miguel J, Belch A, White D, Benboubker L, Cook G, Leiba M, Morton J, Ho PJ, Kim K, Takezako N, Moreau P, Kaufman JL, Sutherland HJ, Lalancette M, Magen H, Iida S, Kim JS, Prince HM, Cochrane T, Oriol A, Bahlis NJ, Chari A, O'Rourke L, Wu K, Schecter JM, Casneuf T, Chiu C, Soong D, Sasser AK, Khokhar NZ, Avet-Loiseau H and Usmani SZ: Daratumumab plus lenalidomide and dexamethasone versus lenalidomide and dexamethasone in relapsed or refractory multiple myeloma: Updated analysis of pollux. Haematologica 103(12): 2088-2096, 2018. PMID: 30237262. DOI: 10.3324/ haematol.2018.194282

24 Usmani SZ, Weiss BM, Plesner T, Bahlis NJ, Belch A, Lonial S, Lokhorst HM, Voorhees PM, Richardson PG, Chari A, Sasser AK, Axel A, Feng H, Uhlar CM, Wang J, Khan I, Ahmadi T and Nahi H: Clinical efficacy of daratumumab monotherapy in patients with heavily pretreated relapsed or refractory multiple myeloma. Blood 128(1): 37-44, 2016. PMID: 27216216. DOI: 10.1182/blood-2016-03-705210

25 SmPC Daratumumab. European Medicines Agency. Available at: https://www.ema.europa.eu/en/documents/productinformation/darzalex-epar-product-information_nl.pdf [Last accessed in November 2019]

26 Nooka AK, Gleason C, Sargeant MO, Walker M, Watson M, Panjic EH and Lonial S: Managing infusion reactions to new monoclonal antibodies in multiple myeloma: Daratumumab and elotuzumab. J Oncol Pract 14(7): 414-422, 2018. PMID: 29996069. DOI: 10.1200/jop.18.00143

27 Reece DE and Phillips MJ: Infusion reactions with monoclonal antibody therapy in myeloma: Learning from experience. J Oncol Pract 14(7): 425-426, 2018. PMID: 29996071. DOI: 10.1200/jop.18.00377

28 King T, Jagger J, Wood J, Woodrow C, Snowden A, Haines S, Crosbie $\mathrm{C}$ and Houdyk $\mathrm{K}$ : Best practice for the administration of daratumumab in multiple myeloma: Australian myeloma nurse expert opinion. Asia Pac J Oncol Nurs 5(3): 270-284, 2018. PMID: 29963589. DOI: 10.4103/apjon.apjon_9_18

29 Tzogani K, Penninga E, Schougaard Christiansen ML, Hovgaard D, Sarac SB, Camarero Jimenez J, Garcia I, Lafuente M, 
Sancho-Lopez A, Salmonson T, Gisselbrecht C and Pignatti F: EMA review of daratumumab for the treatment of adult patients with multiple myeloma. Oncologist 23(5): 594-602, 2018. PMID: 29371479. DOI: 10.1634/theoncologist.2017-0328

30 Barr H, Dempsey J, Waller A, Huang Y, Williams N, Sharma N, Benson DM, Rosko AE, Efebera YA and Hofmeister CC: Ninety-minute daratumumab infusion is safe in multiple myeloma. Leukemia 32(11): 2495-2518, 2018. PMID: 29679038. DOI: 10.1038/s41375-018-0120-2

31 SmPC Ipilimumab. European Medicines Agency. Available at: https://www.ema.europa.eu/en/documents/productinformation/yervoy-epar-product-information_nl.pdf [Last accessed in May 2019]

32 Postow MA, Chesney J, Pavlick AC, Robert C, Grossmann K, McDermott D, Linette GP, Meyer N, Giguere JK, Agarwala SS, Shaheen M, Ernstoff MS, Minor D, Salama AK, Taylor M, Ott PA, Rollin LM, Horak C, Gagnier P, Wolchok JD and Hodi FS: Nivolumab and ipilimumab versus ipilimumab in untreated melanoma. N Engl J Med 372(21): 2006-2017, 2015. PMID: 25891304. DOI: 10.1056/NEJMoa1414428

33 Larkin J, Chiarion-Sileni V, Gonzalez R, Grob JJ, Cowey CL, Lao CD, Schadendorf D, Dummer R, Smylie M, Rutkowski P, Ferrucci PF, Hill A, Wagstaff J, Carlino MS, Haanen JB, Maio M, Marquez-Rodas I, McArthur GA, Ascierto PA, Long GV, Callahan MK, Postow MA, Grossmann K, Sznol M, Dreno B, Bastholt L, Yang A, Rollin LM, Horak C, Hodi FS and Wolchok JD: Combined nivolumab and ipilimumab or monotherapy in untreated melanoma. N Engl J Med 373(1): 23-34, 2015. PMID: 26027431. DOI: 10.1056/NEJMoa1504030

34 Robert C, Schachter J, Long GV, Arance A, Grob JJ, Mortier L, Daud A, Carlino MS, McNeil C, Lotem M, Larkin J, Lorigan P, Neyns B, Blank CU, Hamid O, Mateus C, Shapira-Frommer R, Kosh M, Zhou H, Ibrahim N, Ebbinghaus S and Ribas A: Pembrolizumab versus ipilimumab in advanced melanoma. $\mathrm{N}$ Engl J Med 372(26): 2521-2532, 2015. PMID: 25891173. DOI: 10.1056/NEJMoa1503093

35 Ascierto PA, Del Vecchio M, Robert C, Mackiewicz A, Chiarion-Sileni V, Arance A, Lebbe C, Bastholt L, Hamid O, Rutkowski P, McNeil C, Garbe C, Loquai C, Dreno B, Thomas L, Grob JJ, Liszkay G, Nyakas M, Gutzmer R, Pikiel J, Grange F, Hoeller C, Ferraresi V, Smylie M, Schadendorf D, Mortier L, Svane IM, Hennicken D, Qureshi A and Maio M: Ipilimumab 10 $\mathrm{mg} / \mathrm{kg}$ versus ipilimumab $3 \mathrm{mg} / \mathrm{kg}$ in patients with unresectable or metastatic melanoma: A randomised, double-blind, multicentre, phase 3 trial. Lancet Oncol 18(5): 611-622, 2017. PMID: 28359784. DOI: 10.1016/s1470-2045(17)30231-0

36 Momtaz P, Park V, Panageas KS, Postow MA, Callahan M, Wolchok JD and Chapman PB: Safety of infusing ipilimumab over 30 minutes. J Clin Oncol 33(30): 3454-3458, 2015. PMID: 26124475.

37 Gassenmaier M, Lipp HP, Scheu A, Wagner NB, Kofler L, Mueller A, Doecker D, Eigentler TK, Garbe C and Forschner A: Safety of shortened infusion times for combined ipilimumab and nivolumab. Cancer Immunol Immunother 67(1): 135-140, 2018. PMID: 28988363. DOI: 10.1007/s00262-017-2075-y

38 SmPC Mogamulixumab. European Medicines Agency. Available at: https://www.ema.europa.eu/en/documents/productinformation/poteligeo-epar-product-information_nl.pdf [Last accessed in May 2019]

39 Kim YH, Bagot M, Pinter-Brown L, Rook AH, Porcu P, Horwitz SM, Whittaker S, Tokura Y, Vermeer M, Zinzani PL, Sokol L,
Morris S, Kim EJ, Ortiz-Romero PL, Eradat H, Scarisbrick J, Tsianakas A, Elmets C, Dalle S, Fisher DC, Halwani A, Poligone B, Greer J, Fierro MT, Khot A, Moskowitz AJ, Musiek A, Shustov A, Pro B, Geskin LJ, Dwyer K, Moriya J, Leoni M, Humphrey JS, Hudgens S, Grebennik DO, Tobinai K and Duvic $\mathrm{M}$ : Mogamulizumab versus vorinostat in previously treated cutaneous t-cell lymphoma (MAVORIC): An international, openlabel, randomised, controlled phase 3 trial. Lancet Oncol 19(9): 1192-1204, 2018. PMID: 30100375. DOI: 10.1016/s14702045(18)30379-6

40 Ishitsuka K, Yurimoto S, Kawamura K, Tsuji Y, Iwabuchi M, Takahashi $T$ and Tobinai K: Safety and efficacy of mogamulizumab in patients with adult T-cell leukemialymphoma in Japan: Interim results of postmarketing all-case surveillance. Int J Hematol 106(4): 522-532, 2017. PMID: 28597329. DOI: $10.1007 / \mathrm{s} 12185-017-2270-9$

41 SmPC Nivolumab. European Medicines Agency. Available at: https://www.ema.europa.eu/en/documents/productinformation/opdivo-epar-product-information_nl.pdf [Last accessed in August 2019]

42 Waterhouse D, Horn L, Reynolds C, Spigel D, Chandler J, Mekhail T, Mohamed M, Creelan B, Blankstein KB, Nikolinakos P, McCleod MJ, Li A, Oukessou A, Agrawal S and Aanur N: Safety profile of nivolumab administered as 30-min infusion: Analysis of data from checkmate 153. Cancer Chemother Pharmacol 81(4): 679-686, 2018. PMID: 29442139. DOI: 10.1007/s00280-018-3527-6

43 SmPC Ofatumumab. European Medicines Agency. Available at: https://www.ema.europa.eu/en/documents/productinformation/arzerra-epar-product-information_en.pdf [Last accessed in 2015]

44 Osterborg A, Udvardy M, Zaritskey A, Andersson PO, Grosicki S, Mazur G, Kaplan P, Steurer M, Schuh A, Montillo M, Kryachok I, Middeke JM, Kulyaba Y, Rekhtman G, Gorczyca M, Daly S, Chang CN, Lisby S and Gupta I: Phase III, randomized study of ofatumumab versus physicians' choice of therapy and standard versus extended-length ofatumumab in patients with bulky fludarabine-refractory chronic lymphocytic leukemia. Leuk Lymphoma 57(9): 2037-2046, 2016. PMID: 26784000. DOI: 10.3109/10428194.2015.1122783

45 SmPC Panitumumab. European Medicines Agency. Available at: https://www.ema.europa.eu/en/documents/productinformation/vectibix-epar-product-information_nl.pdf [Last accessed in November 2019]

46 Boku N, Sugihara K, Kitagawa Y, Hatake K, Gemma A, Yamazaki N, Muro K, Hamaguchi T, Yoshino T, Yana I, Ueno H and Ohtsu A: Panitumumab in Japanese patients with unresectable colorectal cancer: A post-marketing surveillance study of 3085 patients. Jpn J Clin Oncol 44(3): 214-223, 2014. PMID: 24526771. DOI: 10.1093/jjco/hyt196

47 Stephenson JJ, Gregory C, Burris H, Larson T, Verma U, Cohn A, Crawford J, Cohen RB, Martin J, Lum P, Yang X and Amado RG: An open-label clinical trial evaluating safety and pharmacokinetics of two dosing schedules of panitumumab in patients with solid tumors. Clin Colorectal Cancer 8(1): 29-37, 2009. PMID: 19203894. DOI: 10.3816/CCC.2009.n.005

48 Akiyoshi K, Hamaguchi T, Yoshimura K, Takahashi N, Honma Y, Iwasa S, Takashima A, Kato K, Yamada Y, Onodera H, Takeshita S, Yasui H, Sakai G, Akatsuka S, Ogawa K, Horita Y, Nagai Y and Shimada Y: A prospective, multicenter phase II 
study of the efficacy and feasibility of 15-minute panitumumab infusion plus irinotecan for oxaliplatin- and irinotecan-refractory, $K R A S$ wild-type metastatic colorectal cancer (Short Infusion Of Panitumumab Trial). Clin Colorectal Cancer 17(1): e83-e89, 2018. PMID: 29169974. DOI: 10.1016/j.clcc.2017.10.004

49 SmPC Rituximab (truxima). European Medicines Agency. Available at: https://www.ema.europa.eu/en/documents/productinformation/truxima-epar-product-information_nl.pdf [Last accessed in November 2019]

50 El-Agnaf MR, McCoy C, Ong YL, Eswedi AH, Black B and Ramadan KM: Infusion of rituximab over 90 minutes on an outpatient basis is safe and improves resource utilization. Leuk Lymphoma 48(9): 1875-1877, 2007. PMID: 17786730. DOI: $10.1080 / 10428190701509780$

51 Lang DS, Hagger C and Pearson A: Safety of rapid rituximab infusion in adult cancer patients: A systematic review. Int J Nurs Pract 17(4): 357-369, 2011. PMID: 21781215. DOI: 10.1111/j.1440-172X.2011.01950.X

52 Salar A, Casao D, Cervera M, Pedro C, Calafell M, Abella E, Alvarez-Larran A and Besses C: Rapid infusion of rituximab with or without steroid-containing chemotherapy: 1-yr experience in a single institution. Eur J Haematol 77(4): 338340, 2006. PMID: 16856919. DOI: 10.1111/j.16000609.2006.00713.x

53 Chiang J, Chan A, Shih V, Hee SW, Tao M and Lim ST: A prospective study to evaluate the feasibility and economic benefits of rapid infusion rituximab at an Asian cancer center Int J Hematol 91(5): 826-830, 2010. PMID: 20461562. DOI: 10.1007/s12185-010-0583-z

54 Laudati C, Clark C, Knezevic A, Zhang Z and Barton-Burke M: Hypersensitivity reactions: Priming practice change to reduce incidence in first-dose rituximab treatment. Clin J Oncol Nurs 22(4): 407-414, 2018. PMID: 30035788. DOI: 10.1188/18.Cjon.407-414

55 SmPC Trastuzumab. European Medicines Agency. Available at: https://www.ema.europa.eu/en/documents/productinformation/herceptin-epar-product-information_nl.pdf [Last accessed in September 2019]

56 Thompson LM, Eckmann K, Boster BL, Hess KR, Michaud LB, Esteva FJ, Hortobagyi GN and Barnett CM: Incidence, risk factors, and management of infusion-related reactions in breast cancer patients receiving trastuzumab. Oncologist 19(3): 228-234, 2014. PMID: 24536030. DOI: 10.1634/theoncologist.2013-0286

57 Baselga J, Carbonell X, Castaneda-Soto NJ, Clemens M, Green M, Harvey V, Morales S, Barton C and Ghahramani P: Phase II study of efficacy, safety, and pharmacokinetics of trastuzumab monotherapy administered on a 3-weekly schedule. J Clin Oncol 23(10): 2162-2171, 2005. PMID: 15800309. DOI: 10.1200/ jco.2005.01.014

58 Ring A, Simcock R, Mitra S, Bloomfield D, King J, Simpson S, Sadler $\mathrm{G}$ and Webb A: Infusion of trastuzumab maintenance doses over 30 minutes. Ann Oncol 19(8): 1509-1510, 2008. PMID: 18539615. DOI: 10.1093/annonc/mdn390

59 Abe H, Mori T, Kawai Y, Tomida K, Yamazaki K, Kubota Y, Umeda $\mathrm{T}$ and Tani $\mathrm{T}$ : Safety assessment of intravenous administration of trastuzumab in $100 \mathrm{ml}$ saline for the treatment of HER2-positive breast cancer patients. Asian Pac J Cancer Prev 14(8): 4843-4846, 2013. PMID: 24083756. DOI: 10.7314/apjcp.2013.14.8.4843

60 Oh SY, Lee S, Huh SJ, Lee J, Kim ST, Park SH, Lim HY, Kang WK, Kang BW, Kim JG, Lee HJ, Kim JH, Kang JH and Kim H:
Safety and efficacy of trastuzumab administered as a 30-min infusion in patients with HER2-positive advanced gastric cancer. Cancer Chemother Pharmacol 83(3): 501-508, 2019. PMID: 30535535. DOI: $10.1007 / \mathrm{s} 00280-018-3753-y$

61 Cook-Bruns N: Retrospective analysis of the safety of Herceptin immunotherapy in metastatic breast cancer. Oncology 61 Suppl 2: 58-66, 2001. PMID: 11694789. DOI: 10.1159/000055403

62 Tanz R, Meillan N, Libert N, Magne N, Vedrine L and Chargari $\mathrm{C}$ : Successful readministration of trastuzumab after severe immune reactions in two breast cancer patients. Invest New Drugs 32(3): 573-574, 2014. PMID: 24682736. DOI: 10.1007/s10637-014-0085-6

63 Pivot X, Verma S, Fallowfield L, Muller V, Lichinitser M, Jenkins V, Sanchez Munoz A, Machackova Z, Osborne S and Gligorov J: Efficacy and safety of subcutaneous trastuzumab and intravenous trastuzumab as part of adjuvant therapy for HER2positive early breast cancer: Final analysis of the randomised, two-cohort PrefHer study. Eur J Cancer 86: 82-90, 2017. PMID: 28963915. DOI: 10.1016/j.ejca.2017.08.019

64 Gligorov J, Ataseven B, Verrill M, De Laurentiis M, Jung KH, Azim HA, Al-Sakaff N, Lauer S, Shing M and Pivot X: Safety and tolerability of subcutaneous trastuzumab for the adjuvant treatment of human epidermal growth factor receptor 2-positive early breast cancer: SafeHer phase III study's primary analysis of 2573 patients. Eur J Cancer 82: 237-246, 2017. PMID: 28625777. DOI: 10.1016/j.ejca.2017.05.010

65 Lugtenburg P, Avivi I, Berenschot H, Ilhan O, Marolleau JP, Nagler A, Rueda A, Tani M, Turgut M, Osborne S, Smith R and Pfreundschuh M: Efficacy and safety of subcutaneous and intravenous rituximab plus cyclophosphamide, doxorubicin, vincristine, and prednisone in first-line diffuse large B-cell lymphoma: The randomized MabEase study. Haematologica 102(11): 1913-1922, 2017. PMID: 28935843. DOI: 10.3324/haematol.2017.173583

66 Davies A, Merli F, Mihaljevic B, Mercadal S, Siritanaratkul N, Solal-Celigny P, Boehnke A, Berge C, Genevray M, Zharkov A, Dixon M, Brewster M, Barrett M and MacDonald D: Efficacy and safety of subcutaneous rituximab versus intravenous rituximab for first-line treatment of follicular lymphoma (SABRINA): A randomised, open-label, phase 3 trial. Lancet Haematol 4(6): e272-e282, 2017. PMID: 28476440. DOI: 10.1016/s2352-3026(17)30078-9

67 SmPC Atezolizumab. European Medicines Agency. Avalaible at: https://www.ema.europa.eu/en/documents/productinformation/tecentriq-epar-product-information_nl.pdf [Last accessed in June 2019]

68 Miller K, Wang M, Gralow J, Dickler M, Cobleigh M, Perez EA, Shenkier T, Cella D and Davidson NE: Paclitaxel plus bevacizumab versus paclitaxel alone for metastatic breast cancer. N Eng J Med 357(26): 2666-2676, 2007. PMID: 18160686. DOI: $10.1056 /$ NEJMoa072113

69 Saltz LB, Clarke S, Diaz-Rubio E, Scheithauer W, Figer A, Wong R, Koski S, Lichinitser M, Yang TS, Rivera F, Couture F, Sirzen F and Cassidy J: Bevacizumab in combination with oxaliplatin-based chemotherapy as first-line therapy in metastatic colorectal cancer: A randomized phase III study. J Clin Oncol 26(12): 2013-2019, 2008. PMID: 18421054. DOI: 10.1200/ jco.2007.14.9930

70 SmPC Blinatumomab. European Medicines Agency. Available at: https://www.ema.europa.eu/en/documents/product- 
information/blincyto-epar-product-information_nl.pdf

[Last accessed in June 2019]

71 Bonner JA, Harari PM, Giralt J, Azarnia N, Shin DM, Cohen RB, Jones CU, Sur R, Raben D, Jassem J, Ove R, Kies MS, Baselga J, Youssoufian H, Amellal N, Rowinsky EK and Ang KK: Radiotherapy plus cetuximab for squamous-cell carcinoma of the head and neck. N Engl J Med 354(6): 567-578, 2006. PMID: 16467544. DOI: 10.1056/NEJMoa053422

72 Rivera F, Garcia-Castano A, Vega N, Vega-Villegas ME and Gutierrez-Sanz L: Cetuximab in metastatic or recurrent head and neck cancer: The EXTREME trial. Expert Rev Anticancer Ther 9(10): 1421-1428, 2009. PMID: 19828002. DOI: 10.1586/era.09.113

73 Price TJ, Peeters M, Kim TW, Li J, Cascinu S, Ruff P, Suresh AS, Thomas A, Tjulandin S, Zhang K, Murugappan S and Sidhu $\mathrm{R}$ : Panitumumab versus cetuximab in patients with chemotherapy-refractory wild-type KRAS exon 2 metastatic colorectal cancer (ASPECCT): A randomised, multicentre, openlabel, non-inferiority phase 3 study. Lancet Oncol 15(6): 569-579, 2014. PMID: 24739896. DOI: 10.1016/s1470-2045(14)70118-4

74 SmPC Dinutuximab beta. European Medicines Agency. Available at: https://www.ema.europa.eu/en/documents/productinformation/qarziba-epar-product-information_nl.pdf [Last accessed in August 2019]

75 SmPC Durvalumab. European Medicines Agency. Available at: https://www.ema.europa.eu/en/documents/productinformation/imfizi-epar-product-information_nl.pdf [Last accessed in June 2019]

76 Berenson J, Manges R, Badarinath S, Cartmell A, McIntyre K, Lyons R, Harb W, Mohamed H, Nourbakhsh A and Rifkin R: A phase 2 safety study of accelerated elotuzumab infusion, over less than $1 \mathrm{~h}$, in combination with lenalidomide and dexamethasone, in patients with multiple myeloma. Am J Hematol 92(5): 460-466, 2017. PMID: 28213943. DOI: 10.1002/ajh.24687

77 SmPC Elotuzumab. European Medicines Agency. Available at: https://www.ema.europa.eu/en/documents/productinformation/empliciti-epar-product-information_nl.pdf [Last accessed in November 2019]

78 SmPC Obinutuzumab. European Medicines Agency. Available at: https://www.ema.europa.eu/en/documents/productinformation/gazyvaro-epar-product-information_nl.pdf [Last accessed in November 2019]

79 SmPC Pembrolizumab. European Medicines Agency. Available at: https://www.ema.europa.eu/en/documents/productinformation/keytruda-epar-product-information_nl.pdf [Last accessed in June 2019]

80 SmPC Pertuzumab. European Medicines Agency. Available at: https://www.ema.europa.eu/en/documents/productinformation/perjeta-epar-product-information_nl.pdf [Last accessed in July 2019]

81 SmPC Ramucirumab. European Medicines Agency. Available at: https://www.ema.europa.eu/en/documents/productinformation/cyramza-epar-product-information_nl.pdf [Last accessed in July 2019]
82 Al Zahrani A, Ibrahim N and Al Eid A: Rapid infusion rituximab changing practice for patient care. J Oncol Pharm Pract 15(3): 183186, 2009. PMID: 19171551. DOI: 10.1177/1078155208100527

83 Sehn LH, Donaldson J, Filewich A, Fitzgerald C, Gill KK, Runzer N, Searle B, Souliere S, Spinelli JJ, Sutherland J and Connors JM: Rapid infusion rituximab in combination with corticosteroid-containing chemotherapy or as maintenance therapy is well tolerated and can safely be delivered in the community setting. Blood 109(10): 4171-4173, 2007. PMID: 17244675. DOI: $10.1182 /$ blood-2006-11-059469

84 Tuthill M, Crook T, Corbet T, King J and Webb A: Rapid infusion of rituximab over $60 \mathrm{~min}$. Eur J Haematol 82(4): 322325, 2009. PMID: 19220420. DOI: 10.1111/j.16000609.2009.01215.x

85 Provencio M, Cerdeira S, Bonilla F, Sanchez A and Espana P: Rapid-infusion rituximab in lymphoma treatment. Ann Oncol 17(6): 1027-1028, 2006. PMID: 16322113. DOI: 10.1093/annonc/mdj103

86 Yokoyama M, Terui Y, Takeuchi K, Nara E, Nakano K, Ueda K, Nishimura N, Mishima Y, Sakajiri S, Tsuyama N, Ozawa K and Hatake K: Infusion rate escalation study of rituximab in patients with CD $20^{+}$B-cell lymphomas: A single-institution analysis in japan. ISRN Oncol 2013: 863909, 2013. PMID: 23691364. DOI: $10.1155 / 2013 / 863909$

87 Siano M, Lerch E, Negretti L, Zucca E, Rodriguez-Abreu D, Oberson M, Leoncini L, Mora O, Sessa C, Gallino A and Ghielmini M: A phase I-II study to determine the maximum tolerated infusion rate of rituximab with special emphasis on monitoring the effect of rituximab on cardiac function. Clin Cancer Res 14(23): 7935-7939, 2008. PMID: 19047125. DOI: 10.1158/1078-0432.Ccr-08-1124

88 SmPC Siltuximab. Cell lymphomas. Available at: https:// www.ema.europa.eu/en/documents/product-information/sylvantepar-product-information_nl.pdf [Last accessed in August 2018]

89 von Minckwitz G, Colleoni M, Kolberg HC, Morales S, Santi P, Tomasevic Z, Zhang N and Hanes V: Efficacy and safety of ABP 980 compared with reference trastuzumab in women with HER2-positive early breast cancer (LILAC study): A randomised, double-blind, phase 3 trial. Lancet Oncol 19(7): 987-998, 2018. PMID: 29880292. DOI: 10.1016/s14702045(18)30241-9

90 Ardavanis A, Tryfonopoulos D, Orfanos G, Karamouzis M, Scorilas A, Alexopoulos A and Rigatos G: Safety and efficacy of trastuzumab every 3 weeks combined with cytotoxic chemotherapy in patients with HER2-positive recurrent breast cancer: Findings from a case series. Onkologie 28(11): 558-564, 2005. PMID: 16249641. DOI: 10.1159/000088608

Received January 10, 2019

Revised February 4, 2020

Accepted February 12, 2020 